\title{
Sarcoidosis: Pitfalls and Challenging Mimickers
}

\author{
Naureen Narula* and Michael lannuzzi \\ Staten Island University Hospital, New York, NY, United States
}

Sarcoidosis, a systemic granulomatous disease of unknown etiology, may mimic other conditions at presentation often resulting in delayed diagnosis. These conditions include infections, neoplasms, autoimmune, cardiovascular, and drug-induced diseases. This review highlights the most common sarcoidosis mimics that often lead to pitfalls in diagnosis and delay in appropriate treatment. Prior to invasive testing and initiating immunosuppressants (commonly corticosteroids), it is important to exclude sarcoid mimickers.

Keywords: sarcoidosis, cardiac sarcoidosis (CS), neurosarcoidosis, hypercalcemia (HCM), hypersentivity pneumonitis, sarcoidosis associated pulmonary hypertension, aseptic meningitis

\section{INTRODUCTION}

OPEN ACCESS

Edited by:

Peter Korsten,

University Medical Center

Göttingen, Germany

Reviewed by:

Cheng-De Yang,

Shanghai Jiao Tong University, China

Wonder Drake,

Vanderbilt University, United States

*Correspondence:

Naureen Narula

drnaureennarula@gmail.com

Specialty section:

This article was submitted to

Rheumatology,

a section of the journal

Frontiers in Medicine

Received: 12 August 2020 Accepted: 30 October 2020

Published: 11 January 2021

Citation:

Narula N and lannuzzi M (2021)

Sarcoidosis: Pitfalls and Challenging Mimickers. Front. Med. 7:594275.

doi: 10.3389/fmed.2020.594275
Jonathon Hutchinson, an English physician, first described sarcoidosis in 1877 (1). Over the last few decades, substantial progress has been made to better define the clinical, radiological, immunological, and pathological features of sarcoidosis. The diagnosis of sarcoidosis is based on three major criteria: clinical presentation compatible with sarcoidosis, presence of non-necrotizing granulomatous inflammation in one or more tissue samples, and the exclusion of alternative causes of granulomatous disease. The American Thoracic Society recently published an official clinical practice guideline in which a panel of experts discuss and summarize evidence-based diagnosis of sarcoidosis (2). Despite advancements clinicians often remain challenged in reaching a diagnosis of sarcoidosis.

\section{Infections}

Nearly all infectious causes of granulomas may present similarly to sarcoidosis (Table 1) (3-7) thus excluding an infectious etiology must be routine and relies more on laboratory studies rather than differentiating clinical features. Table 1 highlights the recommended laboratory studies to be considered during the workup of a patient. Sarcoidosis is an often overlooked cause of fever of unknown origin (FUO) (8). About one-third of patients with sarcoidosis exhibit non-specific constitutional findings such as fever, lethargy, night sweats, and weight loss.

In developing countries with high $\mathrm{TB}$ burdens, diagnosing sarcoidosis can be particularly challenging. TB is classically characterized by caseating granulomas whereas sarcoidosis has noncaseating epithelioid cell granulomas. However, when caseous necrosis is not seen and acidfast staining of biopsy specimens is negative then a patient with suspected TB infection can be mistakenly diagnosed with sarcoidosis (3). In an endemic area, clinical judgment is crucial. Radiological findings of upper lobe predominant cavitary lesions favor the diagnosis of TB, as cavity formation occurs in only $3 \%$ of sarcoidosis cases (9).

Endobronchial ultrasound-guided transbronchial needle aspiration (EBUS-TBNA) to obtain TB-PCR samples makes ruling out TB more certain. In a study by Eom et al., 86 specimens were examined in 46 patients and the sensitivity, specificity, positive predictive value, negative predictive 
TABLE 1 | Infectious causes of granulomas and the laboratory studies to consider to rule out infection.

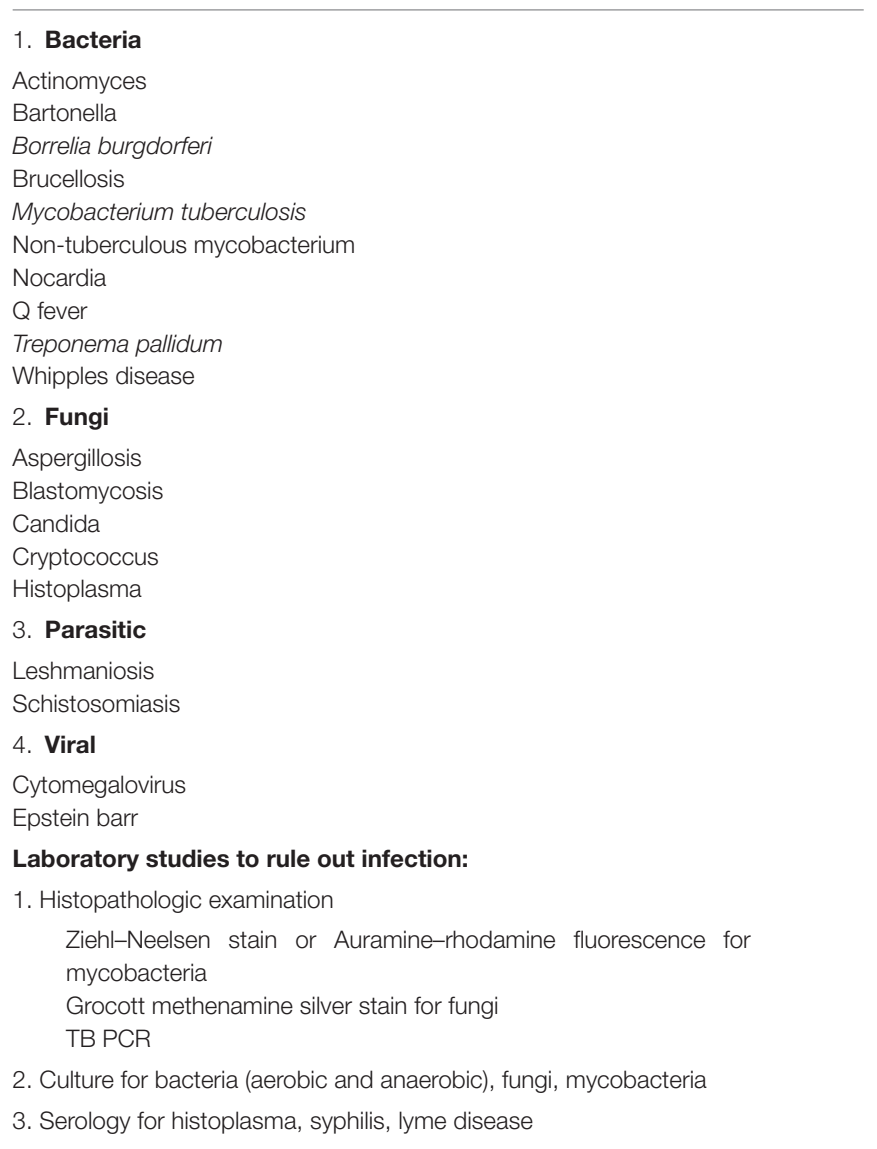

value, and diagnostic accuracy were analyzed. EBUS-TBNA TB PCR was found to be $56 \%, 100 \%$, for sensitivity and specificity, respectively. Positive and negative predictive values were $100 \%$, and $81 \%$. Diagnostic accuracy was $85 \%(10)$. Characterization of sonographic features of lymph nodes by an EBUS can also aid in differentiating TB associated lymphadenopathy (LAD) from sarcoidosis. Dhooria et al. analyzed 250 EBUS-guided TBNA procedures in patients with intrathoracic LAD and found that sonographic features of heterogeneous echotexture and coagulation necrosis are suggestive of TB rather than sarcoidosis. A combination of a positive tuberculin skin test (TST) and either heterogeneous echotexture or coagulation necrosis sign had a specificity of $98 \%$ and a positive predictive value of $91 \%$ for a diagnosis of tuberculosis (11).

Heterogeneous echotexture (53.4 vs. $12.6 \%, P<0.001)$ and coagulation necrosis (26.1 vs. $3.3 \%$; $P<0.001)$ are suggestive of TB rather than sarcoidosis. A combination of a positive tuberculin skin test (TST) and either heterogeneous echotexture or coagulation necrosis sign had a specificity of $98 \%$ and positive predictive value of $91 \%$ for a diagnosis of tuberculosis (11). Use of an interferon- $\gamma($ IFN- $\gamma)$ release assay has been reported to demonstrate a better predictive ability than tuberculin skin tests (12). Culture although time-consuming is still considered as a gold standard test for the diagnosis of Tuberculosis (13).
An accurate and timely diagnosis of sarcoidosis helps prevent unnecessary antituberculosis therapy (ATT) drug exposure. An accurate diagnosis of TB prevents exposure to immunosuppressive agents. Concomitant tuberculosis and sarcoidosis is rare (14).

The presence of exudative pleural effusions may favor other diagnoses. Pleural effusions associated with sarcoidosis are uncommon (8.2\%) and can be present at the time of diagnosis or at a later time, coinciding with an exacerbation $(15,16)$. These effusions are typically right sided, exudative, and lymphocytic predominant. Eosinophilic and neutrophilic effusions have been reported, but are less common. Pleural fluid in sarcoidosis is characterized by having a high CD4/CD8 ratio and frequently sarcoid related pleural effusions resolve spontaneously but still may require treatment with corticosteroids (17).

The presence of an exudative effusion in the setting of sarcoidosis warrants infectious workup e.g., parapneumonic effusion, or empyema. Patients on immunosuppressive agents are particularly susceptible to opportunistic infections (18-20). The failure of pleural effusions to respond to corticosteroid treatment should raise suspicion for an underlying opportunistic infection or other complications such as pulmonary embolism. Table 2 highlights the characteristic differentiating features in patients with common infectious etiologies which can mimic sarcoidosis.

\section{GRANULOMATOUS CHRONIC INTERSTITIAL LUNG DISEASE}

Along with sarcoidosis, granuloma formation is a feature of other chronic interstitial lung diseases such as chronic beryllium disease (CBD) and hypersensitivity pneumonitis (HP).

\section{Chronic Beryllium Disease (CBD)}

Chronic beryllium disease (CBD) is clinically and pathologically indistinguishable from sarcoidosis. CBD risk is associated with fluorescent light manufacturing and in industries such as nuclear energy, ceramics, aerospace, automotive, electronics, and telecommunications (42). Non-occupational exposure to CBD has been reported in family members of factory workers likely due to second-hand exposure and in residents of communities near the beryllium factories.

Symptoms of CBD include dry cough, progressive dyspnea on exertion, fatigue, and night sweats. The radiological features vary with common chest CT findings including small nodules, ground-glass opacification, mild hilar adenopathy, and septal lines. A diagnosis of CBD is favored over sarcoidosis when there is documented occupational exposure to beryllium. Beryllium exposure should be considered at the time of sarcoidosis diagnosis as well as in chronic corticosteroid-resistant sarcoidosis to ensure they are removed from ongoing exposure to immunosuppressants.

A diagnosis of $\mathrm{CBD}$ can be aided by the following three criteria: (1) symptomatic disease with a histopathological demonstration of non-caseating granuloma, pulmonary function impairment, and abnormal chest radiographs; (2) proof of beryllium sensitization by two independently positive beryllium 
TABLE 2 | Highlights the characteristic differentiating features in patients with common infectious etiologies which can mimic sarcoidosis.

\begin{tabular}{|c|c|c|c|c|}
\hline & Features & Sarcoidosis & Mycobacterium tuberculosis & Histoplasmosis \\
\hline A & $\begin{array}{l}\text { Lab findings } \\
\text { 1. ACE level } \\
\text { 2. Abnormal calcium } \\
\text { metabolism } \\
\text { 3. Kveim-Siltzbach test } \\
\text { 4. Mantoux test } \\
\text { 5. Other diagnostic } \\
\text { tests }\end{array}$ & $\begin{array}{l}\text { Elevated ACE (50-80\%) (19-21) } \\
\text { Elevated vitamin D } \\
\text { Hypercalcemia } \\
\text { Hypercalciuria (22) } \\
\text { Positive in } 60 \% \text { (23) } \\
\text { Anergic; Negative in 90\% (24) }\end{array}$ & $\begin{array}{l}\text { Elevated ACE in } 9 \%(22,25) \\
\text { Hypovitaminosis D } \\
\text { Hypercalcemia rare but can be } \\
\text { seen in MTB IRD cases }(26) \\
\text { Negative } \\
\text { Positive in } 65-94 \%(27,28) \\
\text { PCR MTB }\end{array}$ & $\begin{array}{l}\text { Elevated in } 25 \%(29,30) \\
\text { Hypercalcemia rare but can be seen (31) } \\
\text { Negative } \\
\text { Negative } \\
\text { Histoplasma antigen in urine (sensitivity 93-100\%) } \\
\text { (Gold standard test) and serum (32) } \\
\text { - PCR assays for the Hcp } 100 \text { gene } \\
\text { - Histoplasmin sensitivity skin test }\end{array}$ \\
\hline B & BAL findings & $\begin{array}{l}\text { - CD4/CD8 ratio >3.5 (33) } \\
\text { - Elevated ACE }(34,35)\end{array}$ & $\begin{array}{l}\text { BAL AFB smear (sensitivity } \\
38.1 \%) \\
\text { BAL culture (sensitivity } 74.5 \%) \\
(35,36) \\
\text { Elevated CD4+/CD8 }{ }^{+} \text {ratio (37) }\end{array}$ & Histoplasmosis Antigen in BAL (38) \\
\hline D & $\begin{array}{l}\text { 1. Radiological Hilar } \\
\text { and mediastinal LAD } \\
\text { 2. EBUS }\end{array}$ & $\begin{array}{l}\text { Bilateral Hilar LAD when present } \\
\text { is symmetrical } \\
\text { Nodules } \\
\text { Reticulonodular opacities } \\
\text { Cavitation rare } \\
\text { Granular appearance in lymph } \\
\text { nodes -highest specificity } \\
(99.3 \%) \text { for the diagnosis of } \\
\text { sarcoidosis (39). }\end{array}$ & $\begin{array}{l}\text { Asymmetrical, unilateral } \\
\text { Upper-lobe infiltrates with } \\
\text { cavitation, tree-in-bud, } \\
\text { macro-nodular infiltrates (3). } \\
\text { Cavitation is more common (9) } \\
\text { Heterogeneous echotexture } \\
(53.4 \% P<0.001 \text { ) and } \\
\text { coagulation necrosis ( } 26.1 \% P< \\
0.001 \text { ) (11) }\end{array}$ & $\begin{array}{l}\text { Asymmetrical, unilateral (40) } \\
\text { Fibrosing mediastinitis } \\
\text { Reticulonodular opacities } \\
\text { Cavitation is rare (41) } \\
\text { Non-specific }\end{array}$ \\
\hline E & Treatment & $\begin{array}{l}\text { Immunosuppressant like } \\
\text { corticosteroids }\end{array}$ & ATT & $\begin{array}{l}\text { Itraconazole, AMB } \\
\text { Streptomycin }\end{array}$ \\
\hline
\end{tabular}

AFB, Acid Fast Bacill; ATT, Anti-Tuberculosis Treatment; AMB, Amphotericin B; MTB, Mycobacterium tuberculosis; LAD, Lymphadenopathy; PCR, Polymerase Chain Reaction; MTB-IRD, Mycobacterium tuberculosis Immune Reconstitution Disease.

lymphocyte proliferation assays (BeLPTs) in the absence of treatment with systemic corticosteroids for preceding 3 months, and (3) proof of beryllium exposure $(43,44)$. Beryllium sensitization is diagnosed when either criteria 2 or 3 are fulfilled without criterium 1.

Management of suspected CBD involves stopping all further exposure and continued clinical surveillance. Therapy with corticosteroids may be beneficial in selected patients, but the response is variable. Oral prednisone (doses ranging from 20 to $40 \mathrm{mg} /$ day) for 3-6 months followed by a gradual taper to the lowest effective dose is deemed acceptable. Unfortunately, CBD is typically a progressive disease and lifelong treatment may be required. BeLPT should be offered to any patient with sarcoidosis who has worked around metal-dust or fumes (45).

\section{Hypersensitivity Pneumonitis}

Hypersensitivity pneumonitis (HP) has clinical, radiological, and histopathological features that overlap with sarcoidosis. HP pathogenesis results from a combination of immune complexmediated (type III) and delayed-type (type IV) hypersensitivity reactions to antigen inhalation in a susceptible person. Cryptogenic HP is a subtype of HP in which despite typical HP features an inciting exposure is not identified (46-48).
Table 3 illustrates comparative features between hypersensitivity pneumonitis and sarcoidosis.

HP can be categorized by disease duration into acute, subacute, and chronic subtypes (60). Raghu et al. recently proposed categorization based on the presence or absence of radiological and/or histopathological fibrosis into either fibrotic HP or non-fibrotic HP, which has been widely accepted (61).

The median age at diagnosis is 65 years which is somewhat older than what is typical of sarcoidosis (20-39 years). Common presenting symptoms of HP include dyspnea, cough, wheezing, and, less frequently, constitutional symptoms such as weight loss. Physical examination may reveal the presence of rales. An acute presentation is more consistent with the non-fibrotic subtype and an insidious presentation is more consistent with fibrotic HP $(47,62,63)$.

The radiological features of HP depend upon the subtype. Typical radiologic features of non-fibrotic HP include highresolution CT (HRCT) showing parenchymal infiltration with ground-glass opacities (GGO), and mosaic attenuation. HRCT may also demonstrate small airway disease, which can be described as ill-defined, small $(<5 \mathrm{~mm})$ centrilobular nodules on inspiratory images and air trapping on expiratory images, both in a diffuse distribution. Typical radiological features associated 
TABLE 3 | Compares the characteristics of CBD with sarcoidosis across various clinical characteristics, lab abnormalities, and imaging studies.

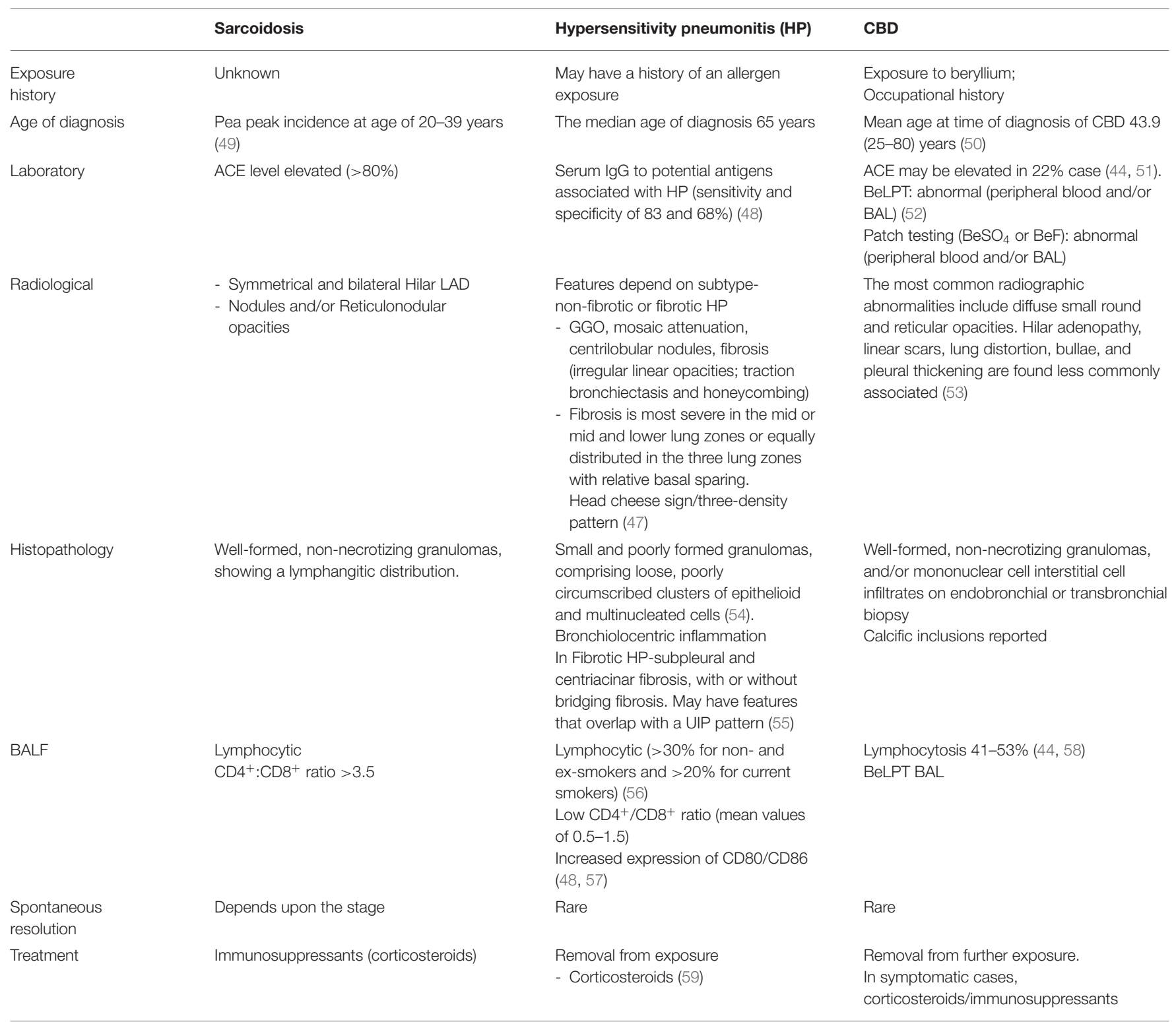

ACE, angiotensin converting enzyme; BALF, bronchoalveolar fluid; BeLPT, beryllium lymphocyte proliferation assay; CBD, chronic beryllium disease.

with fibrotic HP include an HRCT pattern of irregular linear opacities and or/coarse reticulation with lung distortion; traction bronchiectasis and honeycombing, all typical of lung fibrosis, and at least one abnormality that indicates small airway disease. The presence of three different lung densities, previously referred by radiologists as "head-cheese sign" and recently being referred to as the "three-density pattern," is characteristically associated with HP (61). Radiologically, granulomas associated with HP are interstitial and do not follow the lymphatics as in sarcoid. Also, sarcoidosis normally spares the lung bases. For both HP and advanced sarcoidosis, a prognosis-predicting factor is the extent of the fibrotic score calculated on HRCT scans $(64,65)$. Further, HRCT can help differentiate active inflammation from fibrosis in patients with advanced-stage sarcoidosis (66). Honeycombing is uncommon in sarcoidosis but if present usually involves the middle and upper lung zones with relative sparing of the lung bases. The presence of lower lung honeycombing would make it difficult to distinguish between HP, sarcoidosis, and idiopathic pulmonary fibrosis (59).

Bronchoalveolar lavage fluid (BALF) analysis of patients with HP reveals a predominance of lymphocytes, like sarcoidosis. A meta-analysis of 53 studies ( 3,112 patients) by Raghu et al. demonstrated that patients with HP had a higher proportion of BALF lymphocytes than patients with sarcoidosis (MD, 19\%; $95 \%$ CI, 17-21\%). This was found regardless of whether the study enrolled patients with non-fibrotic HP (17 studies; MD, 25\%; 95\% CI, 22-27\%), fibrotic HP (16 studies; MD, 16\%; 95\% CI, 11$20 \%$ ), or mixed populations with both non-fibrotic and fibrotic 
HP (21 studies; MD, 18\%; 95\% CI, 15-20\%). For distinguishing non-fibrotic HP from sarcoidosis, BALF lymphocyte thresholds of 20,30 , and $40 \%$ yielded decreased sensitivities for HP of 95 , 88 , and $76 \%$, respectively, but increased specificities of 26,43 , and $61 \%$, respectively, with an area under the curve of $0.71(95 \% \mathrm{CI}$, 0.67-0.74) (61).

A diagnosis of HP requires:

1. The presence of an exposure, defined as a positive exposure history, serum IgG testing against potential antigens associated with HP, and/or specific inhalation challenge

2. BALF revealing lymphocytosis or histopathological findings on biopsy

3. Typical radiographic features as described above (GGO and mosaic attenuation for non-fibrotic HP and fibrotic changes with small airway involvement for fibrotic HP).

A diagnosis of HP can be made with high confidence in patients with an identified provocative exposure and who have a typical HP radiological pattern on HRCT and with BALF revealing predominant lymphocytosis. For less straightforward cases, a multidisciplinary team consisting of a pulmonologist experienced in interstitial lung disease (ILD), a chest radiologist, and when necessary, a pathologist familiar with histopathological features of ILD and HP.

Treatment involves prompt and complete avoidance of further exposure to the inducer. Systemic corticosteroids are used in treatment however, their use has no effect on long-term outcomes and is often reserved for patients with more severe symptoms (67, 68). Fibrotic HP is associated with worse prognosis particularly with persistent exposure to the inciting agent, cigarette smoking, lower baseline vital capacity, and lack of BALF lymphocytosis $(49,62,69,70)$. Patients with the progressive disease should be evaluated for lung transplantation (55).

\section{THROMBOSIS; PULMONARY HYPERTENSION}

When presented with a patient with sarcoidosis and worsening shortness of breath, an assessment for pulmonary embolism (PE) and pulmonary hypertension $(\mathrm{PH})$ is warranted. $\mathrm{PE}$ and sarcoidosis associated pulmonary hypertension (SAPH) may often be misdiagnosed as an exacerbation of sarcoidosis.

\section{VENOUS THROMBOEMBOLISM (VTE) ASSOCIATED WITH SARCOIDOSIS}

Sarcoidosis, as with other chronic inflammatory conditions, has been associated with an increased risk of venous thromboembolism (VTE) (71-73). Swigris et al. reported a greater than 2-fold higher risk of pulmonary embolism in patients with sarcoidosis when compared to the general population (74). In addition to $\mathrm{PE}$, thrombosis secondary to localized inflammation has also been reported in the literature. Mural thrombosis in myocardial sarcoidosis, cerebral vein thrombosis in neurosarcoidosis and thoracic vein thrombosis in mediastinal sarcoidosis have all been reported (75-77). While the precise mechanism is not yet defined, chronic inflammation associated with sarcoidosis likely predisposes to endothelial cell injury with the inflammatory cytokines activating the coagulation cascade (78-80). Extrinsic vascular compression at a mediastinal or hilar level may lead to venous stasis thus progressing to localized thrombosis (77). Up to $38 \%$ of sarcoidosis patients demonstrate the presence of antiphospholipid antibodies (81). The use of glucocorticoids further increases the risk of VTE (82).

\section{SARCOIDOSIS-ASSOCIATED PULMONARY HYPERTENSION (SAPH)}

Fischer et al. reported elevated pulmonary-artery pressure in 6$23 \%$ of patients at rest and in as many as $43 \%$ with exertion (83). SAPH has been reported in up to $74 \%$ of patients with advanced sarcoidosis $(84,85)$. In one case-series, Schorr et al. reported a 7 fold increased risk for death over a 3-year follow-up in patients with SAPH (86). Pulmonary fibrosis leading to obliteration of the pulmonary vessels is considered the most common mechanism for developing $\mathrm{PH}$ (84). SAPH is classified as World Health Organization (WHO) group 5 due to its complex and multifactorial mechanisms (87). The optimal management for pulmonary hypertension in sarcoidosis is not well-defined. Along with treatment directed at active sarcoid inflammation (corticosteroid and steroid-sparing agents), therapy should focus on correcting hypoxia when present and managing comorbidities such as sleep apnea and cardiac dysfunction. Reduced diffusing capacity of the lung for carbon monoxide (DLCO) correlates with the severity of SAPH (88). Currently, the use of pulmonary hypertension specific therapy for the management of SAPH is controversial, and thus far pulmonary arterial hypertension specific therapies have not been approved $(89,90)$. Lung transplantation may also be considered in this high risk group. A reduced DLCO $(<35 \%$ predicted) and a $6 \mathrm{MWD}$ of $<300 \mathrm{~m}$ are associated with worse transplant-free survival. Oksana et al. identified preservation of FEV1/FVC ratio as an independent risk factor for worsened outcomes (91).

\section{NEUROSARCOIDOSIS AND ITS POTENTIAL MIMICS-ASEPTIC MENINGITIS AND MULTIPLE SCLEROSIS}

Any part of the nervous system may be involved in sarcoidosis. Neurological involvement occurs in 5-15\% of patients and often precedes the diagnosis of sarcoidosis in up to $74 \%$. Neurological Involvement most commonly affects cranial nerves (Cranial nerve VII and II are most common), the hypothalamus and the pituitary gland followed by the meninges, brainstem, spinal cord are less frequently involved (92-96).

Neurosarcoidosis can mimic other neurologic diseases including neoplasm (lymphoma, metastasis) (97), infectious etiologies (meningoencephalitis) (98) and other inflammatory diseases (angiitis/vasculitis, demyelinating disorders). Neurosarcoidosis can present as multiple supratentorial and/or infratentorial masses (35\%) or solitary masses (15\%) (99). The differential diagnosis includes gliomas, primary B 
cell lymphoma, metastatic disease, infarct, and demyelinating disease. Motor dysfunction is present in up to $50 \%$ of cases. Patients can demonstrate neuropsychiatric manifestations such as depression, psychoses, dementia, poor concentration, and hallucinations (100-102).

\section{CENTRAL INVOLVEMENT}

\section{Aseptic Meningitis Associated With Sarcoidosis}

Cerebrospinal Fluid (CSF) findings in neurosarcoidosis may reveal elevated protein (50-70\% of patients), elevated CSF pressure with a lymphocytic pleocytosis (57-72\% of patients), and a reduced glucose level (up to $18 \%$ patients). None of these abnormalities are specific for neurosarcoidosis. Several studies evaluated the role of elevated CSF angiotensinconverting enzyme (ACE) level for diagnosing neurosarcoidosis $(103,104)$. The sensitivity of CSF ACE varies depending on the location of the central nervous system (CNS) involvement. For example, higher levels are rarely seen with spinal cord involvement (105). The ACE assay is not a specific test as it can be elevated in bacterial and viral encephalitis, neurosyphilis, malignant CNS tumors, Huntington's disease, multiple sclerosis and neuroleptic-treated schizophrenic patients (106). Steroid therapy can decrease the ACE level (103).

In suspected neurosarcoidosis associated aseptic meningitis, CSF should be sent for routine microbiological studies, fungal, and mycobacterium cultures, mycobacterium TB polymerase chain reaction (PCR). Cytology and flow cytometry should also be considered. Once the infection has been ruled out, corticosteroids can be initiated as first-line treatment. In sarcoidosis, both aseptic meningitis and isolated cranial nerve abnormalities usually respond to steroids. Corticosteroids can be started at $1 \mathrm{mg} / \mathrm{kg}$ or as a pulse of methylprednisolone $(1,000$ $\mathrm{mg} /$ day for 3 days). Steroids may be gradually reduced over the next 6-9 months. In steroid-refractory cases, methotrexate, azathioprine, cyclophosphamide, or mycophenolate should be considered. Radiotherapy has been reported in patients with refractory sarcoid meningitis but has been used infrequently $(92,107,108)$.

\section{Multiple Sclerosis}

One of the most challenging presentations is in patients, typically young women, with optic neuritis and finding a few demyelinating lesions on brain MRI. The clinical presentation of both neurosarcoidosis and multiple sclerosis (MS) include both these features. While over $90 \%$ of MS patients have oligoclonal bands on CSF analysis, oligoclonal bands can be seen in up to $25-50 \%$ of neurosarcoidosis patients making distinguishing sarcoidosis from multiple sclerosis more difficult (109-112). Neurosarcoidosis involvement on MRI demonstrates non-enhancing T2 and FLAIR white matter lesions often in a periventricular distribution mimicking the demyelinating lesions seen in MS $(111,113)$. Both MS and neurosarcoidosis can follow a relapsing or progressive course. A timely and correct diagnosis is essential because the misdiagnosis of neurosarcoidosis would prevent the patient from receiving highly effective MS therapies. Additionally, exposure to neurosarcoidosis specific therapies such as TNF-alpha antagonists may worsen MS (114, 115).

Table 4 illustrates the characteristic clinical and radiological features of Neurosarcoidosis, aseptic Meningitis and MS.

The diagnostic workup in a patient with a suspicion of neurosarcoidosis mimicking MS should include chest CT to search for lymphadenopathy and a full-body positron emission tomography (PET) scan to search for other organ involvement that supports the diagnosis of sarcoidosis, e.g., FDG uptake in thoracic lymph nodes, lung, spleen, and bone. PET scans can also direct tissue biopsy for histologic confirmation (118).

Diagnostic criteria proposed by Zajicek et al. categorizes neurosarcoidosis into definitive, probable, and possible neurosarcoidosis (130). Definite neurosarcoidosis is defined as clinical presentation suggestive of neurosarcoidosis after the exclusion of other possible diagnoses with the histological evidence of sarcoid in the nervous system. Probable neurosarcoidosis is defined as a suggestive clinical presentation of neurosarcoidosis in a patient with systemic sarcoid and after alternative diagnoses have been excluded. Possible neurosarcoidosis is defined as clinical presentation suggestive of neurosarcoidosis after alternative diagnoses have been excluded.

MRI is the preferred mode of imaging for diagnosis and follow up of neurosarcoidosis as it carries a high sensitivity. Leptomeningeal enhancement favors a diagnosis of sarcoidosis over neoplasm (123, 130-132). Enhancing parenchymal masses are an infrequent but important manifestation of sarcoidosis, but may also occur in primary lymphoma of the brain $(97,133)$. A CNS biopsy may be indicated when there is no extra-neurological disease, particularly if a lack of response to immunosuppressive treatment occurs. MRI can reveal accessible locations for biopsy, preferably from the leptomeninges (113).

Immunosuppression has been the mainstay of treatment for neurosarcoidosis with corticosteroids being the firstline. Other steroid-sparing therapeutic agents include methotrexate, mycophenolate mofetil, azathioprine, cyclosporine, cyclophosphamide, chlorambucil, pentoxifylline, hydroxychloroquine, thalidomide, infliximab, and adalimumab (134).

\section{Peripheral Involvement}

Peripheral nervous system involvement includes mononeuropathy, mononeuritis multiplex, sensory, sensorimotor, and motor polyneuropathies. Symptoms may be acute, subacute, or chronic. An acute generalized demyelinating motor neuropathy similar to the Guillain-Barré syndrome also has been described (135). Small fiber neuropathy resulting in distal limb pain and impaired perception of temperature, hyperesthesia, and autonomic dysfunction have been recognized (136).

Steroid-induced remissions coupled with frequent relapses observed in patients with neurosarcoidosis can lead to a clinical picture that resembles an inflammatory demyelinating disease. Neurologic involvement may be more difficult to confirm as tissue biopsy may be impractical (137-139). 
TABLE 4 | Highlights the features of aseptic meningitis secondary to viral etiology and neuro-sarcoidosis associated meningitis.

\begin{tabular}{|c|c|c|c|}
\hline & Sarcoidosis & Multiple sclerosis & $\begin{array}{l}\text { Aseptic meningitis associated with } \\
\text { viral infection }\end{array}$ \\
\hline Laboratory & $\begin{array}{l}\text { Elevated ACE level } \\
\text { Abnormal calcium metabolism } \\
\text { (hypercalciuria and/or hypercalcemia) } \\
(7,12)\end{array}$ & Non-specific laboratory findings & $\begin{array}{l}\text { Enteroviruses most common, arboviruses, } \\
\text { herpesviruses, influenza, mumps, HIV } \\
(109,116,117) \text {. }\end{array}$ \\
\hline Eye involvement & $\begin{array}{l}\text { Anterior uveitis } \\
\text { Acute Bilateral optic neuritis }(118,119)\end{array}$ & $\begin{array}{l}\text { Unilateral optic neuritis, pain on eye } \\
\text { movement, partial and mainly central visual } \\
\text { blurring, normal disc or mild disc swelling }\end{array}$ & Ocular involvement not common. \\
\hline Myelopathy & $\begin{array}{l}\text { Can progress to spastic paraparesis } \\
\text { MRI spine-meningeal and nerve root } \\
\text { involvement (120) }\end{array}$ & $\begin{array}{l}\text { Can progress to spastic paraparesis } \\
\text { MRI spine-no meningeal enhancement } \\
\text { has been reported. }\end{array}$ & Myelopathy is not common. \\
\hline CSF findings & $\begin{array}{l}\text { Lymphocytic Pleocytosis }(57-72 \% \\
\text { patients) } \\
\text { Elevated Protein ( } 50-70 \% \text { patients) } \\
\text { Low glucose }(18 \% \text { patients) } \\
\text { CSF ACE elevated } 50 \% \text { patients } \\
\text { Oligoclonal bands } \\
\text { Elevated CSF pressure finding of Kveim } \\
\text { specific IgG in CSF }(89,121,122)\end{array}$ & $\begin{array}{l}\text { Mild Lymphocytic Pleocytosis }\left(<50 / \mathrm{mm}^{3}\right) \\
\text { Protein may be elevated in } 1 / 3 \text { cases. } \\
\text { Normal glucose and pressure }(123,124) \\
\text { Oligoclonal bands or elevated IgG index in } \\
\text { CSF (125) }\end{array}$ & $\begin{array}{l}\text { Mononuclear pleocytosis (may be } \\
\text { neutrophilic in early stage) } \\
\text { Protein concentration can be normal to } \\
\text { elevated (typically } 0.4-0.8 \mathrm{~g} / \mathrm{l}) \text {. } \\
\text { Normal to low glucose } \\
\text { CSF PCR specific for virus (enterovirus, } \\
\text { HSV, VZV (109) }\end{array}$ \\
\hline MRI findings & $\begin{array}{l}\text { Variable contrast enhancement of the } \\
\text { leptomeninges with a nodular or diffuse } \\
\text { pattern, non-specific white matter lesions, } \\
\text { and hydrocephalus. }\end{array}$ & $\begin{array}{l}\text { Oval, asymmetric white matter lesions } \\
\text { perpendicular to the ventricles (Dawson } \\
\text { fingers) or in the periventricular, } \\
\text { juxtacortical, infratentorial or spinal cord } \\
\text { region, and having a diameter }>6 \mathrm{~mm} \text { are } \\
\text { considered typical of MS }(54,126-129)\end{array}$ & $\begin{array}{l}\text { MRI demonstrates abnormalities specific } \\
\text { to the viral etiological agent (107) }\end{array}$ \\
\hline Treatment & Corticosteroids & Corticosteroids, DMDs & $\begin{array}{l}\text { Supportive management } \\
\text { Acyclovir in HSV }\end{array}$ \\
\hline
\end{tabular}

CSF, Cerebrospinal fluid; MRI, Magnetic resonance imaging; PCR, Polymerase chain reaction; DMDs, Disease-modifying drugs; ACE, Angiotensin converting enzyme; MRI, magnetic resonance imaging.

\section{ABNORMAL CALCIUM METABOLISM}

Harrel et al. first described hypercalcemia associated with sarcoidosis in 1939 and since then abnormal calcium metabolism is considered a key feature of sarcoidosis. Hypercalcemia in sarcoidosis is secondary to an uncontrolled synthesis of 1,25dihydroxy vitamin D3 by macrophages present in granulomas. The increased 1,25 dihydroxyvitamin D3 leads to increased intestinal absorption of calcium that leads to increased resorption of calcium in the bone $(140,141)$. The most common manifestation of abnormal calcium metabolism is hypercalciuria which is prevalent in $\sim 40-62 \%$ (119). Patients often provide a history of nephrolithiasis.

In the kidney, untreated hypercalcemia causes afferent arteriole vasoconstriction and inhibition of sodium-potassium ATPase causing a decrease in glomerular filtration rate and urinary sodium wasting, polyuria, and dehydration. Increased intracellular calcium overload and tubular obstruction by calcium precipitates may lead to tubular necrosis. Renal consequences of hypercalcemia and hypercalciuria are frequently reversible, however, long-standing hypercalciuria may lead to nephrocalcinosis and permanent changes $(142,143)$.

Once hypercalcemia is detected, serum albumin, ionized calcium, and 24-h urine collection for calcium excretion should be measured. In cases of progressive renal impairment, $24 \mathrm{~h}$ creatinine clearance, and abdominal ultrasound should also be performed to exclude nephrolithiasis or nephrocalcinosis. Primary hyperparathyroidism should routinely be ruled out. Histologic confirmation of sarcoidosis may be required to exclude lymphoma as it has the propensity to present with hypercalcemia associated with lymphadenopathy (144).

\section{MANAGEMENT}

Table 5 highlights the laboratory diagnostics and management of hypercalcemia associated with sarcoidosis.

Asymptomatic and mild hypercalcemia detected in a patient presenting with acute sarcoidosis requires no further assessment, and studies suggest that monitoring the response to corticosteroid therapy is an acceptable practice. Management is aimed to prevent long term renal and bone complications. Patients are advised to maintain a fluid intake of $>21$ per day, minimize their exposure to sunlight, and avoid vitamin D. Severe hypercalcemia is fairly responsive to steroids. Corticosteroids achieve normocalcemia by inhibiting the enzyme 1- $\alpha$-hydroxylase, reducing gastrointestinal calcium absorption, inhibiting osteoclast function, and decreasing the production of parathyroid hormone-related protein (PTHrP) by the macrophages $(31,145-148)$. Early recognition and treatment of abnormal calcium metabolism associated with sarcoidosis is important as long-standing untreated hypercalcemia can 
TABLE 5 | Laboratory and radiological testing along with the management of hypercalcemia associated with sarcoidosis.

\begin{tabular}{|c|c|}
\hline $\begin{array}{l}\text { Laboratory and } \\
\text { radiological tests }\end{array}$ & Management \\
\hline $\begin{array}{l}\text { 24-h urine collection for } \\
\text { calcium excretion. }\end{array}$ & $\begin{array}{l}\text { Hypercalciuria without stone } \\
\text { formation-observational approach; often } \\
\text { requires no treatment. Close monitoring to } \\
\text { prevent renal failure. Treatment options may } \\
\text { include corticosteroids and/or diuretics. }\end{array}$ \\
\hline $\begin{array}{l}\text { Parathyroid Hormone (PTH) } \\
\text { and PTH-related peptide } \\
\text { (PTHrP) }\end{array}$ & $\begin{array}{l}\text { Hypercalciuria with stone } \\
\text { formation-Bisphosphonates or } \\
\text { corticosteroids should be considered; } \\
\text { shockwave lithotripsy }\end{array}$ \\
\hline $\begin{array}{l}\text { Serum creatinine (and/or } \\
\text { cystatin C) }\end{array}$ & Mild, asymptomatic \\
\hline $\begin{array}{l}\text { Serum calcium and albumin } \\
\text { levels should be measured } \\
\text { and the ionized calcium } \\
\text { calculated. }\end{array}$ & $\begin{array}{l}\text { Hypercalcemia - Encourage fluid intake of } \\
>2 \text { I per day and minimize their exposure to } \\
\text { sunlight, avoid vitamin D and fish oil } \\
\text { supplementation. }\end{array}$ \\
\hline $\begin{array}{l}\text { Renal Ultrasound to exclude } \\
\text { nephrolithiasis }\end{array}$ & $\begin{array}{l}\text { Moderate hypercalcemia-May consider } \\
\text { addition of corticosteroids and/or ketoconazole } \\
\text { or hydroxychloroquine. }\end{array}$ \\
\hline $\begin{array}{l}\text { Age appropriate malignancy } \\
\text { work up (To rule out } \\
\text { hypercalcemia secondary } \\
\text { to malignancy) }\end{array}$ & $\begin{array}{l}\text { Severe hypercalcemia - act immediately: } \\
\text { rehydrate. Treatment options include } \\
\text { corticosteroids, calcitonin, loop diuretics, and } \\
\text { bisphosphonates (145) }\end{array}$ \\
\hline
\end{tabular}

progress to irreversible renal failure. It is imperative to consider the implication of the use of corticosteroids in patients as it further increases the risk of developing glucocorticoid-induced osteoporosis (149).

\section{SARCOID-LIKE REACTIONS (SLRs)}

Sarcoid-like reaction (SLR) is defined as the presence of noncaseating epithelioid cell granuloma lesions of sarcoidosis without accompanying systemic symptoms. Sarcoid-like reactions are histologically indistinguishable from systemic sarcoidosis (150).

\section{SARCOID-LIKE REACTIONS (SLRs) ASSOCIATED WITH MALIGNANCY}

SLRs can be observed in patients with various malignancies. The lesions can be adjacent to the primary tumor, in the tumor itself or adjacent to the local draining lymph nodes $(137,151)$. SLRs occur in $4.4 \%$ of carcinomas, in $13.8 \%$ of patients with Hodgkin's disease, and in $7.3 \%$ of cases of non-Hodgkin lymphomas (152). Developing SLRs adjacent to the tumor sites may be due to a local reaction to tumor products or immunological response to an antigenic trigger. SLRs far from tumor sites may represent a host immune response to the soluble circulating tumor antigenic factors perhaps by acting as a type of auto-Kveim reagent (137, 153, 154).

Both SLRs and malignancy demonstrate increased uptake of 18F-fluorodeoxyglucose (FDG) on PET scan, which makes it difficult to distinguish the two. Though PET scans may be useful in selecting possible biopsy sites to search for malignancy, they have no role in differentiating between these two entities. There are no specific markers or radiographic patterns to distinguish SLRs from systemic sarcoidosis or from malignancy (154-157). SLRs may have an improved prognosis as a few studies have reported that SLR is self-limited $(152,158,159)$. The occurrence of malignancy and sarcoidosis concomitantly is unusual but a few cases have been reported $(159,160)$. The development of hilar and/or mediastinal lymphadenopathies in patients with a history of malignancy should prompt considering SLRs. Biopsies of affected tissue are often required to rule out cancer recurrence.

\section{DRUG-INDUCED SARCOIDOSIS-LIKE REACTIONS (DISRs)}

Drug-induced sarcoidosis-like reactions (DISR) can be defined as a granulomatous tissue reaction, indistinguishable from sarcoidosis, that occurs at the same time as initiation of a potential offending drug (161). DISR can be associated with typical sarcoid-like manifestation including bilateral hilar lymphadenopathy, uveitis, hypercalcemia, cutaneous lesions, elevated serum ACE levels, and FDG uptake on PET scans (162166). A variety of drugs have been implicated as causing DISRs including immune checkpoint inhibitors, tumor necrosis factor (TNF)- $\alpha$ antagonists, interferons (IFN), and antiretroviral drugs. It is unclear if the etiology of DISR is that of a sarcoid-like reaction per se or a result of an impaired immune system leading to the development of sarcoidosis while on drug therapy (161).

Although TNF- $\alpha$ is known to play an important role in the formation and stabilization of sarcoid granulomas, surprisingly DISRs have been reported with the use of TNF- $\alpha$ antagonists therapy. Most commonly reported with etanercept, DISRs occur with any of the TNF- $\alpha$ antagonists. The average time to occurrence of DISRs is 24 months after drug initiation with almost $60 \%$ of patients requiring treatment (167). Treatment requirements range from 0 to $59.2 \%$ in reported cases of DISR, depending on the class of drug implicated (Table 6).

DISRs may mimic other clinical manifestations of sarcoidosis such as infections, drug and autoimmune reactions, and neoplasms. In select cases, DISR can resolve with discontinuation of the offending drug $(161,168)$. DISRs that are not associated with significant symptoms, organ dysfunction, or quality of life impairment, do not often require treatment. In cases where treatment is required, standard sarcoidosis treatment regimens can be utilized (161).

\section{IMPLANT AND DEVICE-INDUCED SARCOID-LIKE REACTIONS}

SLRs have been reported after joint replacement surgery and after silicone breast implant placement $(181,182)$. These reactions are postulated to be due to an autoimmune inflammatory syndrome induced by adjuvants (ASIA). The pathogenesis of the development of ASIA is not clearly defined but one proposed mechanism involves adjuvants (i.e., silicone, mineral oil, hyaluronic acid) chronically stimulating the immune pathway and preventing antigens from being degraded which can then 
TABLE 6 | Highlights the drugs commonly associated with DISR.

\begin{tabular}{|c|c|c|c|}
\hline & Drug class & $\begin{array}{l}\text { Percentage of patients } \\
\text { requiring anti-sarcoidosis } \\
\text { treatment }\end{array}$ & References \\
\hline 1. & $\begin{array}{l}\text { Interferon } \\
\text { (interferon } \\
\text { alpha and } \\
\text { interferon beta) }\end{array}$ & $42.9 \%$ (158) & $(165,167-169)$ \\
\hline 2. & $\begin{array}{l}\text { Tumor } \\
\text { necrosis } \\
\text { factor- } \alpha \\
\text { antagonist }\end{array}$ & $59.5 \%(158)$ & $(170,171)$ \\
\hline 3. & BRAF inhibitor & $0 \%$ & $(172,173)$ \\
\hline 4. & $\begin{array}{l}\text { Interleukin-1 } \\
\text { receptor } \\
\text { antagonist }\end{array}$ & $0 \%$ & $(174)$ \\
\hline 5. & $\begin{array}{l}\text { Immune } \\
\text { checkpoint } \\
\text { inhibitors } \\
\text { (nivolumab, } \\
\text { pembrolizumab, } \\
\text { ipilimumab) }\end{array}$ & $57.2 \%(158)$ & $(175,176)$ \\
\hline 6. & $\begin{array}{l}\text { Highly active } \\
\text { antiretroviral } \\
\text { therapy } \\
\text { (HAART) }\end{array}$ & $41.1 \%(158)$ & $(177-179)$ \\
\hline 7. & $\begin{array}{l}\text { Botulinum } \\
\text { neurotoxin A }\end{array}$ & 0\% (158) & (180) \\
\hline
\end{tabular}

enhance the antigen exposure to the antigen-presenting cells (APC) $(183,184)$. Definitive treatment requires the removal of the prosthetic implant.

\section{CARDIAC INVOLVEMENT WITH SARCOIDOSIS AND DIFFERENTIATING IT FROM POTENTIAL MIMICS}

In 1929, Bernstein was the first to recognize cardiac involvement in sarcoidosis. Granulomas in cardiac sarcoidosis (CS) most often involve the conduction system and can potentially involve any part of the heart including the pericardium and myocardium (185). Depending upon the location and extent of granulomatous inflammation, clinical manifestation range from asymptomatic conduction abnormalities to fatal heart block and ventricular arrhythmia and congestive heart failure (CHF). In CS, CHF is the second most frequent cause of death after sudden cardiac death. Pericardial effusions are infrequent in CS and rarely progress to cardiac tamponade $(185,186)$.

A timely diagnosis of CS is often difficult as it may present with clinical features and radiographic findings overlapping with other cardiac disorders. Plain chest radiographs may appear normal. Some of the common mimickers of CS cardiomyopathy include amyloidosis and other infiltrative diseases, non-ischemic and ischemic cardiomyopathy, right ventricle infarction, lymphocytic myocarditis, connective tissue diseases associated cardiomyopathy, vasculitis (Takayasu arteritis and Wegener granulomatosis), Chagas disease, hypertrophic cardiomyopathy, and other infectious causes associated with cardiomyopathy (e.g., rheumatic fever, syphilis, fungal infections, and TB) (187-193).

Echocardiographic abnormalities, present in up to $24-77 \%$ of CS patients, range from non-specific findings to more sarcoid associated findings such as thinning of the basal anterior septum, regional wall aneurysm, diastolic dysfunction, or motion wall abnormalities in a non-coronary artery distribution (194). Impaired regional peak systolic longitudinal strain on strain echocardiography has been described and associated with cardiovascular events (195).

Thallium 201 scintigraphy can be used to help distinguish the ischemic disease from sarcoidosis or other infiltrative diseases. The reverse distribution phenomenon on rest and exercise thallium described as defects detected in the resting phase during thallium scanning that disappears or decreases in size during exercise or after dipyridamole infusion (196). Cardiac PET scanning may be combined with MRI to further define CS involvement. The sensitivities of cardiac PET and MRI with contrast are about the same for detecting myocardial involvement. Late gadolinium enhancement (LGE) on MRI generally cannot distinguish scar from inflammation while FDG uptake implies active inflammation $(197,198)$. Cardiac PET scanning is particularly useful in patients unable to undergo cardiac MRI because of the presence of implantable cardiac devices or renal failure where gadolinium is contraindicated.

Infrequently, granulomatous infiltration of the myocardium can result in myocardial thickening which can morphologically mimic hypertrophic cardiomyopathy but unlike CS, which is characterized by inflammation and edema, T2-weighted MRI features not typically seen in hypertrophic cardiomyopathy. Areas of Late gadolinium- enhancement (LGE) in CS are more likely to be patchy and mid myocardial.

For cardiac amyloid which is a consideration for unexplained infiltrative disease, both 99mTcpyrophosphate scanning and tissue biopsy (fat pad) showing apple-green birefringence at polarizing light microscopy are distinguishing features (199201). In patients with CS and extracardiac involvement lymph node or lung biopsy is typically targeted but in cases of negative extracardiac biopsy or isolated CS, MRI, or PET directed endomyocardial biopsy may be required. Electroanatomic mapping can also be used to choose cardiac sites for biopsy $(202,203)$.

CS can be managed with corticosteroids and when necessary inotropic, vasodilator, and antiarrhythmic medications. Automatic Implantable Cardioverter Defibrillator (AICD) or cardiac pacing may have a role. Cardiac transplantation although rare can be considered in younger patients with advanced end-stage cardiac failure. No difference in outcome has been reported when transplants are done for CS (204-207).

\section{COMMON VARIABLE IMMUNODEFICIENCY SYNDROME (CVID)}

Common variable immunodeficiency syndrome may be complicated by granulomatous lymphocytic interstitial lung 
disease (GLILD) (206). The presence of sarcoidosis like lesions associated with hypogammaglobulinemia should suggest a diagnosis of CVID as up to $8-22 \%$ of patients with CVID can present with GILD (208-210). In a retrospective analysis more than two-thirds of CVID patients with radiographic evidence of interstitial lung disease had GLILD. GLILD was also frequently reported with dyspnea and splenomegaly. These patients can present with a clinical picture that mimics sarcoidosis and misdiagnosis can delay the treatment for CVID (IVIG), which in the presence of GLILD portends a poorer prognosis. Steroid therapy can further worsen CVID (209, 211-213).

Key clinical features that should alert one to the diagnosis of CVID include a history of recurrent infections (214) and a concurrent diagnosis of autoimmune diseases. Concurrent autoimmune disease occurs much less frequently in sarcoidosis than CVID. Sarcoidosis is more commonly associated with uveitis and skin disease whereas CVID patients more frequently have autoimmune cytopenias. Comparing GLID to sarcoidosis, chest CT scans had more air bronchogram, halo signs, and smooth bordered nodules in the CVID group. Bronchoalveolar lavage (BAL) revealed lower T-cell CD4: CD8 as well in the CVID group $(215,216)$.

With the aid of B cell immunophenotyping, granulomas associated with CVID reveal a severe reduction in switched memory B cells and a high level of CD21 low B cells. Immunoglobulin perfusions are considered the treatment of

\section{REFERENCES}

1. Hutchinson J. Case of livid papillary psoriasis. In: Illustrations of Clinical Surgery, Vol. 1. London: J\&A Churchill (1877). p. 42-3.

2. Crouser ED, Maier LA, Wilson KC, Bonham CA, Morgenthau AS, Patterson $\mathrm{KC}$, et al. Diagnosis and detection of sarcoidosis. An official American thoracic society clinical practice guideline. Am J Respir Crit Care Med. (2020) 201:e26-51. doi: 10.1164/rccm.202002-0251ST

3. Badar F, Azfar SF, Ahmad I, Yasmeen S, Kirmani S. Diagnostic difficulties in differentiating sarcoidosis from tuberculosis. Oman Med J. (2011) 26:210-1. doi: 10.5001/omj.2011.53

4. Mortaz E, Adcock IM, Barnes PJ. Sarcoidosis: role of non-tuberculosis mycobacteria and Mycobacterium tuberculosis. Int J Mycobacteriol. (2014) 3:225-9. doi: 10.1016/j.ijmyco.2014.10.008

5. Moravvej H, Vesal P, Abolhasani E, Nahidi S, Mahboudi F. Comorbidity of leishmania major with cutaneous sarcoidosis. Indian J Dermatol. (2014) 59:316. doi: 10.4103/0019-5154.131453

6. Sicherman HJ, Andersen HA, DeRemee RA. Sarcoidosis or fungal disease. Chest. (1973) 64:36-7. doi: 10.1378/chest.64.1.36

7. Paramothayan S, Jones PW. Corticosteroid therapy in pulmonary sarcoidosis: a systematic review. JAMA. (2002) 287:1301-7. doi: 10.1001/jama.287.10.1301

8. Telenti A, Hermans PE. Idiopathic granulomatosis manifesting as fever of unknown origin. Mayo Clin Proc. 64:44-50. doi: 10.1016/S0025-6196(12)65302-6

9. Grenier P, Valeyre D, Cluzel P, Brauner MW, Lenoir S, Chastang C. Chronic diffuse interstitial lung disease: diagnostic value of chest radiography high-resolution CT. Radiology. (1991) 179:123-32. doi: 10.1148/radiology.179.1.2006262

10. Eom JS, Mok JH, Lee MK, Lee K, Kim MJ, Jang SM, et al. Efficacy of TB-PCR using EBUS-TBNA samples in patients with intrathoracic granulomatous lymphadenopathy. BMC Pulm Med. (2015) 15:166. doi: 10.1186/s12890-015-0162-4

11. Dhooria S, Agarwal R, Aggarwal AN, Bal A, Gupta N, Gupta D. Differentiating tuberculosis from sarcoidosis by sonographic characteristics choice for CVID (217). Measurement of serum immunoglobulins should be considered when a history of recurrent infections is given and should be considered in any patient with granulomatous disease, even if the clinical and radiological presentation appears typical for sarcoidosis (218).

\section{CONCLUSION}

As illustrated by the numerous diseases that sarcoidosis can imitate, sarcoidosis deserves the reputation of "The Great Mimicker." The purpose of this review the most common diseases that should be considered when sarcoidosis enters the differential diagnoses. Aside from the time lost for adequate treatment of the disease present, both using immunosuppressive drugs in a state that appears to be sarcoidosis or conversely failing to adequately treat sarcoidosis with its proper treatment regimen will lead to adverse outcomes. The authors herein described common pitfalls in the diagnostic process and how to avoid them in order to provide, to the best of our ability, an accurate diagnosis for a condition that continues to baffle, elude, and mislead clinicians.

\section{AUTHOR CONTRIBUTIONS}

All authors contributed equally in data collection, interpretation, paper writing, editing, and review.

of lymph nodes on endobronchial ultrasonography: a study of 165 patients. $J$ Thorac Cardiovasc Surg. (2014) 148:662-7. doi: 10.1016/j.jtcvs.2014.01.028

12. Zhou G, Luo Q, Luo S, Teng Z, Ji Z, Yang J, et al. Interferon- $\gamma$ release assays or tuberculin skin test for detection and management of latent tuberculosis infection: a systematic review and meta-analysis. Lancet Infect Dis. (2020). doi: 10.1016/S1473-3099(20)30276-0

13. Afsar I, Gunes M, Er H, Gamze Sener A. Comparison of culture, microscopic smear and molecular methods in diagnosis of tuberculosis. Rev Esp Quimioter. (2018) 31:435-8.

14. Wong CF, Yew WW, Wong PC, Lee J. A case of concomitant tuberculosis and sarcoidosis with mycobacterial DNA present in the sarcoid lesion. Chest. (1998) 114:626-9. doi: 10.1016/S0012-3692(15)47782-7

15. Szwarcberg JB, Glajchen N, Teirstein AS. Pleural involvement in chronic sarcoidosis detected by thoracic CT scanning. Sarcoidosis Vasc Diffuse Lung Dis. (2005) 22:58-62.

16. Soskel NT, Sharma OP. Pleural involvement in sarcoidosis. Curr Opin Pulm Med. (2000) 6:455-68. doi: 10.1097/00063198-200009000-00012

17. Huggins JT, Doelken P, Sahn SA, King L, Judson MA. Pleural effusions in a series of 181 outpatients with sarcoidosis. Chest. (2006) 129:1599-604. doi: 10.1378/chest.129.6.1599

18. Sadikot RT, Dore P, Arnold AG. Sarcoidosis and opportunistic infections. South Med J. (2001) 94:75-7. doi: 10.1097/00007611-200194010-00016

19. Nottebart HC, McGehee RF, Utz JP. Cryptococcosis complicating sarcoidosis. Am Rev Respir Dis. (1973) 107:1060-3.

20. Winterbauer RH, Kraemer KG. The infectious complications of sarcoidosis: a current perspective. Arch Intern Med. (1976) 136:1356-62. doi: 10.1001/archinte.1976.03630120008006

21. Ungprasert P, Carmona EM, Crowson CS, Matteson EL. Diagnostic utility of angiotensin-converting enzyme in sarcoidosis: a population-based study. Lung. (2016) 194:91-5. doi: 10.1007/s00408-015-9826-3

22. Sharma OP. Markers of sarcoidosis activity. Chest. (1986) 90:471-3. doi: $10.1378 /$ chest.90.4.471

23. Shai F, Baker RK, Addrizzo JR, Wallach S. Hypercalcemia in mycobacterial infection. J Clin Endocrinol Metab. (1972) 34:251-6. doi: 10.1210/jcem-34-2-251 
24. Khasawneh FA, Ahmed S, Halloush RA. Progressive disseminated histoplasmosis presenting with cachexia and hypercalcemia. Int J Gen Med. (2013) 6:79-83. doi: 10.2147/IJGM.S41520

25. Studdy PR, Bird R. Serum angiotensin converting enzyme in sarcoidosisits value in present clinical practice. Ann Clin Biochem. (1989) 26:13-8. doi: 10.1177/000456328902600102

26. Thillai M, Eberhardt C, Lewin AM, Potiphar L, Hingley-Wilson S, Sridhar $\mathrm{S}$, et al. Sarcoidosis and tuberculosis cytokine profiles: indistinguishable in bronchoalveolar lavage but different in blood. PLoS ONE. (2012) 7:e38083. doi: 10.1371/journal.pone.0038083

27. Iannuzzi MC, Rybicki BA, Teirstein AS. Sarcoidosis. $N$ Engl J Med. (2007) 357:2153-65. doi: 10.1056/NEJMra071714

28. Gupta D, Chetty M, Kumar N, Aggarwal AN, Jindal SK. Anergy to tuberculin in sarcoidosis is not influenced by high prevalence of tuberculin sensitivity in the population. Sarcoidosis Vasc Diffuse Lung Dis. (2003) 20:40-5.

29. Khan AH, Ghani F, Khan A, Khan MA, Khurshid M. Role of serum angiotensin converting enzyme in sarcoidosis. J Pak Med Assoc. (1998) 48:131-3.

30. Ryder KW, Jay SJ, Kiblawi SO, Hull MT. Serum angiotensin converting enzyme activity in patients with histoplasmosis. JAMA. (1983) 249:1888-9. doi: 10.1001/jama.1983.03330380076032

31. Young C, Burrows R, Katz J, Beynon H. Hypercalcemia in sarcoidosis. Lancet. (1999) 353:374. doi: 10.1016/S0140-6736(98)08251-8

32. Regatieri A, Abdelwahed Y, Perez MT, Bush LM. Testing for tuberculosis: the roles of tuberculin skin tests and interferon gamma release assays. Lab Med. (2011) 42:11-6. doi: 10.1309/LMU57KYINZ6WJTIT

33. Kantrow SP, Meyer KC, Kidd P, Raghu G. The CD4/CD8 ratio in BAL fluid is highly variable in sarcoidosis. Eur Respir J. (1997) 10:2716-21.

34. Pottumarthy S, Morris AJ, Harrison AC, Wells VC. Evaluation of the tuberculin gamma interferon assay: potential to replace the Mantoux skin test. J Clin Microbiol. (1999) 37:3229-32.

35. Connolly PA, Durkin MM, Lemonte AM, Hackett EJ, Wheat LJ. Detection of histoplasma antigen by a quantitative enzyme immunoassay. Clin Vaccine Immunol. (2007) 14:1587-91. doi: 10.1128/CVI.00071-07

36. Danila E, Norkuniene J, Jurgauskiene L, Malickaite R. Diagnostic role of BAL fluid CD4/CD8 ratio in different radiographic and clinical forms of pulmonary sarcoidosis. Clin Respir J. (2009) 3:214-21. doi: 10.1111/j.1752-699X.2008.00126.x

37. Kalawat U, Sharma KK, Reddy PN, Kumar AG. Study of bronchoalveolar lavage in clinically and radiologically suspected cases of pulmonary tuberculosis. Lung India. (2010) 27:122-4. doi: 10.4103/0970-2113. 68307

38. Conde MB, Soares SL, Mello FC, Rezende VM, Almeida LL, Reingold $\mathrm{AL}$, et al. Comparison of sputum induction with fiberoptic bronchoscopy in the diagnosis of tuberculosis: experience at an acquired immune deficiency syndrome reference center in Rio de Janeiro, Brazil. Am J Respir Crit Care Med. (2000) 162:2238-40. doi: 10.1164/ajrccm.162.6.20 03125

39. Greco S, Marruchella A, Massari M, Saltini C. Predictive value of BAL cellular analysis in differentiating pulmonary tuberculosis and sarcoidosis. Eur Respir J. (2005) 26:360-2. doi: 10.1183/09031936.05.00042905

40. Glazer CS, Rose CS, Lynch DA. Clinical and radiologic manifestations of hypersensitivity pneumonitis. J Thorac Imaging. (2002) 17:261-72. doi: 10.1097/00005382-200210000-00003

41. Hage CA, Davis TE, Fuller D, Egan L, Witt JR 3rd, Wheat LJ, et al. Diagnosis of histoplasmosis by antigen detection in BAL fluid. Chest. (2010) 137:623-8. doi: 10.1378/chest.09-1702

42. Hardy HL, Tabershaw IR. Delayed chemical pneumonitis occurring in workers exposed to beryllium compounds. J Ind Hyg Toxicol. (1946) 28:197-211.

43. Newman LS, Kreiss K, King TE Jr, Seay S, Campbell PA. Pathologic and immunologic alterations in early stages of beryllium disease. Re-examination of disease definition and natural history. Am Rev Respir Dis. (1989) 139:1479-86. doi: 10.1164/ajrccm/139.6.1479

44. Balmes JR, Abraham JL, Dweik RA, Fireman E, Fontenot AP, Maier LA, et al. An official American thoracic society statement: diagnosis and management of beryllium sensitivity and chronic beryllium disease. Am J Respir Crit Care Med. (2014) 190:e34-e59. doi: 10.1164/rccm.201409-1722ST
45. Alberts WM. Lung disease and the lightest of metals. Chest. (2004) 126:17302. doi: $10.1378 /$ chest.126.6.1730

46. Selman M. Hypersensitivity pneumonitis. In: Interstitial Lung Disease. 3rd ed. Hamilton, BC: Decker Inc. (1998). p. 393-422.

47. Lacasse Y, Selman M, Costabel U, Dalphin JC, Ando M, Morell F, et al. Clinical diagnosis of hypersensitivity pneumonitis. Am J Respir Crit Care Med. (2003) 168:952-8. doi: 10.1164/rccm.200301-137OC

48. Walters GI, Mokhlis JM, Moore VC, Robertson AS, Burge GA, Bhomra PS, et al. Characteristics of hypersensitivity pneumonitis diagnosed by interstitial and occupational lung disease multidisciplinary team consensus. Respir Med. (2019) 155:19-25. doi: 10.1016/j.rmed.2019.06.026

49. Vourlekis JS, Schwarz MI, Cherniack RM. The effect of pulmonary fibrosis on survival in patients with hypersensitivity pneumonitis. Am J Med. (2004) 116:662-8. doi: 10.1016/j.amjmed.2003.12.030

50. Müller-Quernheim KI, Gaede E, Fireman G. Zissel Diagnoses of chronic beryllium disease within cohorts of sarcoidosis patients. J Eur Respir J. (2006) 27:1190-5. doi: 10.1183/09031936.06.00112205

51. Newman LS, Orton R, Kreiss K. Serum angiotensin converting enzyme activity in chronic beryllium disease. Am Rev Respir Dis. (1992) 146:39-42. doi: 10.1164/ajrccm/146.1.39

52. Barna BP, Culver DA, Yen-Lieberman B, Dweik RA, Thomassen MJ. Clinical application of beryllium lymphocyte proliferation testing. Clin Diagn Lab Immunol. (2003) 10:990-4. doi: 10.1128/CDLI.10.6.990-994.2003

53. Aronchick JM, Rossman MD, Miller WT. Chronic beryllium disease: diagnosis, radiographic findings, and correlation with pulmonary function tests. Radiology. (1987) 163:677-82. doi: 10.1148/radiology.163.3.3575713

54. Castonguay MC, Ryu JH, Yi ES, Tazelaar HD. Granulomas and giant cells in hypersensitivity pneumonitis. Hum Pathol. (2015) 46:607-13. doi: 10.1016/j.humpath.2014.12.017

55. Kern RM, Singer JP, Koth L, Mooney J, Golden J, Hays S, et al. Lung transplantation for hypersensitivity pneumonitis. Chest. (2015) 147:1558-65. doi: $10.1378 /$ chest.14-1543

56. The BAL Cooperative Group Steering Committee. Bronchoalveolar lavage constituents in healthy individuals, idiopathic pulmonary fibrosis, and selected comparison groups. Am Rev Respir Dis. (1990) 141:S169-202.

57. Rybicki BA, Major M, Popovich J Jr, Maliarik MJ, Iannuzzi MC. Racial differences in sarcoidosis incidence: a 5-year study in a health maintenance organization. Am J Epidemiol. (1997) 145:234-41. doi: 10.1093/oxfordjournals.aje.a009096

58. Ozgul MA, Cetinkaya E, Kirkil G, Ozgul G, Abul Y, Acat M, et al. Lymph node characteristics of sarcoidosis with endobronchial ultrasound. Endosc Ultrasound. (2014) 3:232-7. doi: 10.4103/2303-9027.144541

59. Hamper UM, Fishman EK, Khouri NF, Johns CJ, Wang KP, Siegelman SS. Typical and atypical CT manifestations of pulmonary sarcoidosis. J Comput Assist Tomogr. (1986) 10:928-36. doi: 10.1097/00004728-19861100000006

60. Fink JN, Ortega HG, Reynolds HY, Cormier YF, Fan LL, Franks TJ, et al. Needs and opportunities for research in hypersensitivity pneumonitis. Am J Respir Crit Care Med. (2005) 171:792-8. doi: 10.1164/rccm.200409-1205WS

61. Raghu G, Remy-Jardin M, Ryerson CJ, Myers JL, Kreuter M, Vasakova $\mathrm{M}$, et al. Diagnosis of hypersensitivity pneumonitis in adults. An official ATS/JRS/ALAT clinical practice guideline. Am J Respir Crit Care Med. (2020) 202:e36-69. doi: 10.1164/rccm.202005-2032ST

62. Fernández Pérez ER, Kong AM, Raimundo K, Koelsch TL, Kulkarni R, Cole AL. Epidemiology of hypersensitivity pneumonitis among an insured population in the United States: a claims-based cohort analysis. Ann Am Thorac Soc. (2018) 15:460-9. doi: 10.1513/AnnalsATS.201704-288OC

63. Ohtani Y, Saiki S, Sumi Y, Inase N, Miyake S, Costabel U, et al. Clinical features of recurrent and insidious chronic bird fancier's lung. Ann Allergy Asthma Immunol. (2003) 90:604-10. doi: 10.1016/S1081-1206(10)61863-7

64. Jeong YJ, Lee KS, Chung MP, Han J, Johkoh T, Ichikado K. Chronic hypersensitivity pneumonitis and pulmonary sarcoidosis: differentiation from usual interstitial pneumonia using high-resolution computed tomography. Semin Ultrasound CT MR. (2014) 35:47-58. doi: $10.1053 /$ j.sult.2013.10.006

65. Sarno M, Hasleton PS, Spiteri M. Sarcoidosis. In: Hasleton PS, editor. Spencer's Pathology of the Lung. 5th ed. New York, NY: McGraw-Hill (1996). p. 507-35. 
66. Nishimura K, Itoh H, Kitaichi M, Nagai S, Izumi T. CT and pathological correlation of pulmonary sarcoidosis. Semin Ultrasound CT MR. (1995) 16:361-70. doi: 10.1016/0887-2171(95)90025-X

67. Kokkarinen JI, Tukiainen HO, Terho EO. Effect of corticosteroid treatment on the recovery of pulmonary function in farmer's lung. Am Rev Respir Dis. (1992) 145:3-5. doi: 10.1164/ajrccm/145.1.3

68. Hsieh C. Hypersensitivity Pneumonitis Treatment \& Management. Medscape Web Site. Available online at: http://emedicine.medscape.com/article/ 299174-treatment (accessed February 8, 2017).

69. Wang P, Jones KD, Urisman A, Elicker BM, Urbania T, Johannson $\mathrm{KA}$, et al. Pathologic findings and prognosis in a large prospective cohort of chronic hypersensitivity pneumonitis. Chest. (2017) 152:502-9. doi: 10.1016/j.chest.2017.02.011

70. Ohtsuka Y, Munakata M, Tanimura K. Smoking promotes insidious and chronic farmer's lung disease, and deteriorates the clinical outcome. Intern Med. (1995) 34:966-71. doi: 10.2169/internalmedicine.34.966

71. Ungprasert P, Crowson CS, Matteson EL. Association of sarcoidosis with increased risk of VTE: a population-based study, 1976 to 2013. Chest. (2017) 151:425-30. doi: 10.1016/j.chest.2016.09.009

72. Ungprasert P, Srivali N, Wijarnpreecha K, Thongprayoon C. Sarcoidosis and risk of venous thromboembolism: a systematic review and meta-analysis. Sarcoidosis Vasc Diffuse Lung Dis. (2015) 32:182-7.

73. Yaqoob ZJ, Al-Kindi SG, Zein JG. Sarcoidosis and risk of VTE: validation with big data. Chest. (2017) 151:1398-9. doi: 10.1016/j.chest.2017.03.022

74. Swigris JJ, Olson AL, Huie TJ, Fernandez-Perez ER, Solomon JJ, Sprunger D, et al. Increased risk of pulmonary embolism among US decedents with sarcoidosis from 1988 to 2007. Chest. (2011) 140:1261-6. doi: 10.1378/chest.11-0324

75. Wynne JW, Ryerson GG, Dalovisio J. Myocardial sarcoidosis complicated by mural thrombosis. Thorax. (1979) 34:127-9. doi: 10.1136/thx.34.1.127

76. Selvi A, Diakou M, Giannopoulos S, Zikou AK, Argyropoulou MI, Kyritsis AP. Cerebral venous thrombosis in a patient with sarcoidosis. Intern Med. (2009) 48:723-5. doi: 10.2169/internalmedicine.48.1809

77. Marc K, Bourkadi JE, Benamor J, Iraqi G. Thoracic venous thrombosis in the course of sarcoidosis. Rev Mal Respir. (2008) 25:105-6. doi: 10.1016/S0761-8425(08)70477-7

78. Silvarino R, Danza A, Merola V. Venous thromboembolic disease is systemic autoimmune diseases: an association to keep in mind. Autoimmun Rev. (2012) 12:289-94. doi: 10.1016/j.autrev.2012.05.002

79. Reitsma PH, Rosendaal FR. Activation of innate immunity in patients with venous thrombosis: the leiden thrombophilia study. J Thromb Haemost. (2004) 2:619-22. doi: 10.1111/j.1538-7836.2004. 00689.x

80. Takizawa H, Satoh M, Okazaki H, Matsuzaki G, Suzuki N, Ishii A, et al. Increased IL-6 and IL-8 in bronchoalveolar lavage fluids (BALF) from patients with sarcoidosis: correlation with the clinical parameters. Clin Exp Immunol. (1997) 107:175-81. doi: 10.1046/j.1365-2249.1997. d01-905.x

81. Ina Y, Takada K, Yamamoto M, Sato T, Ito S, Sato S. Antiphospholipid antibodies. A prognostic factor in sarcoidosis? Chest. (1994) 105:1179-83. doi: $10.1378 /$ chest.105.4.1179

82. Johannesdottir SA, Horvath-Puho E, Dekkers OM. Use of glucocorticoids and risk of venous thromboembolism: a nationwide populationbased case-control study. JAMA Intern Med. (2013) 173:743-52. doi: 10.1001/jamainternmed.2013.122

83. Fisher KA, Serlin DM, Wilson KC, Walter RE, Berman JS, Farber HW. Sarcoidosis-associated pulmonary hypertension: outcome with long-term epoprostenol treatment. Chest. (2006) 130:1481-8. doi: 10.1378/chest.130.5.1481

84. Handa T, Nagai S, Miki S, Fushimi Y, Ohta K, Mishima M, et al. Incidence of pulmonary hypertension and its clinical relevance in patients with sarcoidosis. Chest. (2006) 129:1246-52. doi: 10.1378/chest.129.5.1246

85. Shlobin OA, Nathan SD. Management of end-stage sarcoidosis: pulmonary hypertension and lung transplantation. Eur Respir J. (2012) 39:1520-33. doi: 10.1183/09031936.00175511

86. Shorr AF, Helman DL, Davies DB, Nathan SD. Pulmonary hypertension in advanced sarcoidosis: epidemiology and clinical characteristics. Eur Respir J. (2005) 25:783-8. doi: 10.1183/09031936.05.00083404
87. Simonneau G, Gatzoulis MA, Adatia I, Celermajer D, Denton C, Ghofrani A, et al. Updated clinical classification of pulmonary hypertension. J Am Coll Cardiol. (2013) 62:D34-41. doi: 10.1016/j.jacc.2013.10.029

88. Baughman RP, Shlobin OA, Wells AU, Alhamad EH, Culver DA, Barney J, et al. Clinical features of sarcoidosis associated pulmonary hypertension: Results of a multi-national registry. Respir Med. (2018) 139:72-8. doi: 10.1016/j.rmed.2018.04.015

89. Corte TJ, Wells AU, Nicholson AG, Hansell DM, Wort SJ. Pulmonary hypertension in sarcoidosis: a review. Respirology. (2011) 16:69-77. doi: $10.1111 / \mathrm{j} .1440-1843.2010 .01872 . x$

90. Diaz-Guzman E, Farver C, Parambil J, Culver DA. Pulmonary hypertension caused by sarcoidosis. Clin Chest Med. (2008) 29:549-63. doi: 10.1016/j.ccm.2008.03.010

91. Shlobin OA, Kouranos V, Barnett SD, Alhamad EH, Culver DA, Barney J, et al. Physiological predictors of survival in patients with sarcoidosisassociated pulmonary hypertension: results from an international registry. Eur Respir J. (2020) 55:1901747. doi: 10.1183/13993003.01747-2019

92. Nozaki K, Judson MA. Neurosarcoidosis: clinical manifestations, diagnosis and treatment. Presse Med. (2012) 41:e331-48. doi: 10.1016/j.lpm.2011.12.017

93. Tabuchi S, Uno T. Hydrocephalus with panventricular enlargement as the primary manifestation of neurosarcoidosis: a case report. J Med Case Rep. (2013) 7:240. doi: 10.1186/1752-1947-7-240

94. Rao DA, Dellaripa PF. Extrapulmonary manifestations of sarcoidosis. Rheum Dis Clin North Am. (2013) 39:277-97. doi: 10.1016/j.rdc.2013.02.007

95. Lacomis D. Neurosarcoidosis. Curr Neuropharmacol. (2011) 9:429-36. doi: 10.2174/157015911796557975

96. Agnihotri SP, Singhal T, Stern BJ, et al. Neurosarcoidosis. Semin Neurol. (2014) 34:386-94. doi: 10.1055/s-0034-1390387

97. Tsao CY, Lo WD, Rusin JA, Henwood MJ, Boue DR. Isolated neurosarcoidosis presenting as headache and multiple brain and spinal cord lesions mimicking central nervous system metastases. Brain Dev. (2007) 29:514-8. doi: 10.1016/j.braindev.2006.12.011

98. Galnares-Olalde JA, Berebichez-Fridman R, Gómez-Garza G, Mercado M, Moreno-Sánchez F, Alegría-Loyola MA. Not everything is as it seems: neurosarcoidosis presenting as leptomeningitis. Clin Case Rep. (2018) 6:596602. doi: 10.1002/ccr3.1418

99. Kumar G, Kang CA, Giannini C. Neurosarcoidosis presenting as a cerebellar mass. J Gen Intern Med. (2007) 22:1373-6. doi: 10.1007/s11606-007-0272-7

100. Durel CA, Marignier R, Maucort-Boulch D, Iwaz J, Berthoux E, Ruivard M, et al. Clinical features and prognostic factors of spinal cord sarcoidosis: a multicenter observational study of 20 BIOPSY-PROVEN patients. J Neurol. (2016) 263:981-90. doi: 10.1007/s00415-016-8092-5

101. Matsuda R, Nishimura F, Motoyama Y, Park YS, Nakase H. A case of intraventricular isolated neurosarcoidosis diagnosed by neuroendoscopic biopsy. No Shinkei Geka. (2015) 43:247-52. doi: 10.11477/mf.1436202995

102. Lyra TG, Lee HW, de Vellutini EAS, da Martin MGM, Cardoso APT, de Godoy LFS, et al. Gasserian ganglion neurosarcoidosis mimicking trigeminal schwannoma. Arq Neuropsiquiatr. (2015) 73:173-4. doi: 10.1590/0004-282X20140209

103. Oksanen V. Neurosarcoidosis: clinical presentations and course in 50 patients. Acta Neurol Scand. (1986) 73:283-90. doi: 10.1111/j.1600-0404.1986.tb03277.x

104. Tahmoush AJ, Amir MS, Connor WW, Farry JK, Didato S, Ulhoa-Cintra A, et al. CSF-ACE activity in probable CNS neurosarcoidosis. Sarcoidosis Vasc Diffuse Lung Dis. (2002) 19:191-7.

105. Sakushima K, Yabe I, Nakano F, Yoshida K, Tajima Y, Houzen H, et al. Clinical features of spinal cord sarcoidosis: analysis of 17 neurosarcoidosis patients. J Neurol. (2011) 258:2163-7. doi: 10.1007/s00415-011-6080-3

106. Wahlbeck K, Cheine M, Essali A, Adams C. Evidence of clozapine's effectiveness in schizophrenia: a systematic review and meta-analysis of randomized trials. Am J Psychiatry. (1999) 156:990-9.

107. Dutra LA, Braga-Neto P, Oliveira RA, Pedroso JL, Abrahão A, Barsottini OGP. Neurosarcoidosis: guidance for the general neurologist. Arq Neuropsiquiatr. (2012) 70:293-9. doi: 10.1590/S0004-282X2012000400014

108. Langrand C, Bihan H, Raverot G, Varron L, Androdias G, Borson-Chazot F, et al. Hypothalamo-pituitary sarcoidosis: a multicenter study of 24 patients. Q J Med. (2012) 105:981-95. doi: 10.1093/qjmed/hcs121 
109. Pawate S, Moses H, Sriram S. Presentations and outcomes of neurosarcoidosis: a study of 54 cases. QJM. (2009) 102:449-60. doi: 10.1093/qjmed/hcp042

110. Borucki SJ, Nguyen BV, Ladoulis CT, McKendall RR. Cerebrospinal fluid immunoglobulin abnormalities in neurosarcoidosis. Arch Neurol. (1989) 46:270-3. doi: 10.1001/archneur.1989.00520390036012

111. Scott TF, Yandora K, Kunschner LJ, Schramke C. Neurosarcoidosis mimicry of multiple sclerosis: clinical, laboratory, and imaging characteristics. Neurologist. (2010) 16:386-9. doi: 10.1097/NRL.0b013e3181b $287 \mathrm{df}$

112. Gaines JD, Eckman PB, Remington JS. Low CSF glucose level in sarcoidosis involving the central nervous system. Arch Intern Med. (1970) 125:333-6. doi: 10.1001/archinte.1970.00310020139021

113. Shah R, Roberson GH, Cure JK. Correlation of MR imaging findings and clinical manifestations in neurosarcoidosis. AJNR Am J Neuroradiol. (2009) 30:953-61. doi: 10.3174/ajnr.A1470

114. Ivan Oosten BW, Barkhof F, Truyen L, Boringa JB, Bertelsmann FW, et al. Increased MRI activity and immune activation in two multiple sclerosis patients treated with the monoclonal anti-tumor necrosis factor antibody cA2. Neurology. (1996) 47:1531-4. doi: 10.1212/WNL.47.6.1531

115. The Lenercept Multiple Sclerosis Study Group and the University of British Columbia MS/MRI Analysis Group. TNF neutralization in MS: results of a randomized, placebo-controlled multicenter study. Neurology. (1999) 53:457-65. doi: 10.1212/WNL.53.3.457

116. Kastrup O, Wanke I, Maschke M. Neuroimaging of infections. NeuroRx. (2005) 2:324-32. doi: 10.1602/neurorx.2.2.324

117. Logan SA, MacMahon E. Viral meningitis. BMJ. (2008) 336:36-40. doi: 10.1136/bmj.39409.673657.AE

118. Hebel R, Dubaniewicz-Wybieralska M, Dubaniewicz A. Overview of neurosarcoidosis: recent advances. J Neurol. (2015) 262:258-67. doi: 10.1007/s00415-014-7482-9

119. Taylor R, Lynch H, Wysor WG. Seasonal influence of sunlight on the hypercalcemia of sarcoidosis. Am J Med. (1963) 34:221-7. doi: 10.1016/0002-9343(63)90055-X

120. Burman J, Raininko R, Fagius J. Bilateral and recurrent optic neuritis in multiple sclerosis. Acta Neurol Scand. (2011) 123:207-10. doi: 10.1111/j.1600-0404.2010.01388.x

121. Ratzan KR. Viral meningitis. Med Clin North Am. (1985) 69:399-413. doi: 10.1016/S0025-7125(16)31051-3

122. Kidd DP, Burton BJ, Graham EM, Plant GT. Optic neuropathy associated with systemic sarcoidosis. Neurol Neuroimmunol Neuroinflamm. (2016) 3:e270. doi: 10.1212/NXI.0000000000000270

123. Ginat DT, Dhillon G, Almast J. Magnetic resonance imaging of neurosarcoidosis. J Clin Imaging Sci. (2011) 1:15. doi: 10.4103/2156-7514.76693

124. Fieschi C, Gasperini C, Ristori G, Bastianello S, Girmenia F, Leuzzi V, et al. Diagnostic problems in "clinically definite" multiple sclerosis patients with normal CSF and multiple MRI abnormalities. Eur J Neurol. (1994) 1:127-33. doi: 10.1111/j.1468-1331.1994.tb00060.x

125. Reiber H, Felgenhauer K. Protein transfer at the blood-cerebrospinal fluid barrier and the quantitation of the humoral immune response within the central nervous system. Clin Chim Acta. (1987) 163:319-28. doi: 10.1016/0009-8981(87)90250-6

126. Kabat EA, Freedman DA, Murray JP, Knaub V. A study of the crystalline albumin, gamma globulin and total protein in the cerebrospinal fluid of one hundred cases of multiple sclerosis and in other diseases. Am J Med Sci. (1950) 219:55-64. doi: 10.1097/00000441-195001000-00009

127. Bergamaschi R, Tonietti S, Franciotta D, Candeloro E, Tavazzi E, Piccolo G, et al. Oligoclonal bands in devic's neuromyelitis optica and multiple sclerosis: differences in repeated cerebrospinal fluid examinations. Mult Scler. (2004) 10:2-4. doi: 10.1191/1352458504ms988oa

128. Barkhof F, Filippi M, Miller D, Scheltens P, Campi A, Polman CH, et al. Comparison of MRI criteria at first presentation to predict conversion to clinically definite multiple sclerosis. Brain. (1997) 120:205969. doi: 10.1093/brain/120.11.2059

129. Filippi M, Rocca MA, Bastianello S, Comi G, Gallo P, Gallucci M, et al. Guidelines from the Italian neurological and neuroradiological societies for the use of magnetic resonance imaging in daily life clinical practice of multiple sclerosis patients. Neurol Sci. (2013) 34:2085-93. doi: 10.1007/s10072-013-1485-7

130. Zajicek JP, Scolding NJ, Foster O, Rovaris M, Evanson J, Moseley IF, et al. Central nervous system sarcoidosis-diagnosis and management. QJM. (1999) 92:103-17. doi: 10.1093/qjmed/92.2.103

131. Terushkin V, Stern BJ, Judson MA, Hagiwara M, Pramanik B, Sanchez M, et al. Neurosarcoidosis: presentations and management. Neurologist. (2010) 16:2-15. doi: 10.1097/NRL.0b013e3181c92a72

132. Sherman JL, Stern BJ. Sarcoidosis of the CNS: comparison of unenhanced and enhanced MR images. AJNR Am J Neuroradiol. (1990) 11:915-23.

133. Uruha A, Koide R, Taniguchi M. Unusual presentation of sarcoidosis: solitary intracranial mass lesion mimicking a glioma. J Neuroimaging. (2009) 21:e180-2. doi: 10.1111/j.1552-6569.2009.00413.x

134. Stjepanovic MI, Vucinic VM, Jovanovic D, Mijajlović M, Trifunović VS, Stjepanović MM. Treatment of neurosarcoidosis-innovations and challenges. Med Pregl. (2014) 67:161-6. doi: 10.2298/MPNS1406161S

135. Saifee TA, Reilly MM, Ako E, Rugg-Gunn F, Brandner S, Lunn MP, et al. Sarcoidosis presenting as acute inflammatory demyelinating polyradiculoneuropathy. Muscle Nerve. (2011) 43:296-8. doi: $10.1002 /$ mus. 21890

136. Tavee JO, Karwa K, Ahmed Z, Thompson N, Parambil J, Culver DA. Sarcoidosis-associated small fiber neuropathy in a large cohort: Clinical aspects and response to IVIG and anti-TNF alpha treatment. Respir Med. (2017) 126:135-8. doi: 10.1016/j.rmed.2017.03.011

137. Baughman RP, Lower EE, Du Bois RM. Sarcoidosis. Lancet. (2003) 361:11118. doi: 10.1016/S0140-6736(03)12888-7

138. Spencer TS, Campellone JV, Maldonado I, Huang N, Usmani Q, Reginato AJ. Clinical and magnetic resonance imaging manifestations of neurosarcoidosis. Semin Arthritis Rheum. (2005) 34:649-61. doi: 10.1016/j.semarthrit.2004.07.011

139. Vargas DL, Stern BJ. Neurosarcoidosis: diagnosis and management. Semin Respir Crit Care Med. (2010) 31:419-27. doi: 10.1055/s-0030-1262210

140. Sharma OP. Vitamin D, calcium, and sarcoidosis. Sarcoidosis, hypercalcemia and primary hyperparathyroidism. The vicissitudes of diagnosis. Chest. (1996) 109:535-9. doi: 10.1378/chest.109.2.535

141. Correia FASC, Marchini GS, Torricelli FC, Danilovic A, Vicentini FC Srougi $M$, et al. Renal manifestations of sarcoidosis: from accurate diagnosis to specific treatment. Int Braz J Urol. (2019) 46:15-25. doi: 10.1590/s1677-5538.ibju.2019.0042

142. Berliner AR, Haas M, Choi MJ. Sarcoidosis: the nephrologist's perspective. Am J Kidney Dis. (2006) 48:856-70. doi: 10.1053/j.ajkd.2006. 07.022

143. Hilderson I, Van Laecke S, Wauters A, Donck J. Treatment of renal sarcoidosis: is there a guideline? Overview of the different treatment options. Nephrol Dial Transplant. (2014) 29:1841-7. doi: 10.1093/ndt/gft442

144. Schweitzer VG, Thompson NW, Clark KA, Nishiyama RH, Bigos ST. Sarcoidosis, hypercalcemia and primary hyperparathyroidism. The vicissitudes of diagnosis. Am J Surg. (1981) 142:499-503. doi: 10.1016/0002-9610(81)90383-4

145. Pinkson P, Saltini C, Muller-Quernheim J, Crystal RG. Corticosteroid therapy suppresses spontaneous IL-2 release and spontaneous proliferation of lung T-lymphocytes in patients with sarcoidosis. J Immunol. (1987) 139:755-60.

146. Rizzato G. Clinical impact of bone and calcium changes in sarcoidosis. Thorax. (1998) 53:425-9. doi: 10.1136/thx.53.5.425

147. Hamada K, Nagai S, Tsutsumi T, Izumi T. Ionized calcium and 1,25dihydroxyvitamin D concentration in the serum of patients with sarcoidosis. Eur Respir J. (1998) 11:1015-20. doi: 10.1183/09031936.98.11051015

148. Potts JT. Diseases of the parathyroid gland and other disorders. In: Fauci AS, Braunwald E, editors. Harrison's Principals of Internal Medicine. 14th ed. New York, NY: McGraw-Hill (1998) 354:2236-42.

149. Conron M, Young C, Beynon HLC. Calcium metabolism in sarcoidosis and its clinical implications. Rheumatology. (2000) 39:707-13. doi: 10.1093/rheumatology/39.7.707

150. Martella S, Lohsiriwat V, Barbalho DM, Della Vigna P, Bottiglieri L, Brambullo $\mathrm{T}$, et al. Sarcoid-like reaction in breast cancer: a longterm follow-up series of eight patients. Surg Today. (2012) 42:259-63. doi: 10.1007/s00595-011-0084-6 
151. Tan QL, Leow LC, Haja Mohideen SM, Sewa DW. Sarcoid-like reaction associated with lung adenocarcinoma: a case report. Proc Singapore Healthc. (2019) 28:68-70. doi: 10.1177/2010105818766363

152. Brincker H. Sarcoid reactions in malignant tumours. Cancer Treat Rev. (1986) 13:147-56. doi: 10.1016/0305-7372(86)90002-2

153. Tolaney SM, Colson YL, Gill RR, Schulte S, Duggan MM, Shulman LN, et al. Sarcoidosis mimicking metastatic breast cancer. Clin Breast Cancer. (2007) 7:804-10. doi: 10.3816/CBC.2007.n.044

154. Hunt BM, Vallières E, Buduhan G, Aye R, Louie B. Sarcoidosis as a benign cause of lymphadenopathy in cancer patients. Am J Surg. (2009) 197:629-32. doi: 10.1016/j.amjsurg.2009.01.004

155. Spagnolo P, Luppi F, Roversi P. Sarcoidosis: challenging diagnostic aspects of an old disease. Am J Med. (2012) 125:118-25. doi: 10.1016/j.amjmed.2011.06.003

156. Ravaglia C, Gurioli C, Casoni GL, Romagnoli M, Tomassetti S, Gurioli C, et al. Sarcoid-like lesion is a frequent benign cause of lymphadenopathy in neoplastic patients. Eur Respir J. (2013) 41:754-5. doi: 10.1183/09031936.00141212

157. Chopra A, Judson MA. How are cancer and connective tissue diseases related to sarcoidosis? Curr Opin Pulm Med. (2015) 21:517-24. doi: 10.1097/MCP.0000000000000186

158. Steinfort DP, Tsui A, Grieve J, Hibbs ML, Anderson GP, Irving LB. Sarcoidal reactions in regional lymph nodes of patients with early stage nonsmall cell lung cancer predict improved disease-free survival: a pilot casecontrol study. Hum Pathol. (2012) 43:333-8. doi: 10.1016/j.humpath.2011. 05.006

159. Sacks EL, Donaldson SS, Gordon J, Dorfman RF. Epithelioid granulomas associated with Hodgkin's disease: clinical correlations in 55 previously untreated patients. Cancer. (1978) 41:562-7. doi: 10.1002/10970142(197802)41:2<562::AID-CNCR2820410224>3.0.CO;2-X

160. Sakula A. Bronchial carcinoma and sarcoidosis. Br J Cancer. (1963) 17:20612. doi: 10.1038/bjc.1963.29

161. Chopra A, Nautiyal A, Kalkanis A, Judson MA. Drug-induced sarcoidosislike reactions. Chest. (2018) 154:664-77. doi: 10.1016/j.chest.2018.03.056

162. Danlos FX, Pages C, Baroudjian B, Vercellino L, Battistella M, Mimoun $\mathrm{M}$, et al. Nivolumab-induced sarcoid-like granulomatous reaction in a patient with advanced melanoma. Chest. (2016) 149:e133-6. doi: 10.1016/j.chest.2015.10.082

163. Kim C, Gao J, Shannon VR, Siefker-Radtke A. Systemic sarcoidosis first manifesting in a tattoo in the setting of immune checkpoint inhibition. BMJ Case Rep. (2016) 2016:bcr2016216217. doi: 10.1136/bcr-2016-216217

164. Doycheva D, Deuter C, Stuebiger N, Zierhut M. Interferon-alpha-associated presumed ocular sarcoidosis. Graefes Arch Clin Exp Ophthalmol. (2009) 247:675-80. doi: 10.1007/s00417-008-1002-5

165. Nakajima R, Abe K, Nakajima A, Nishikawa T, Sakai S. Etanercept-induced sarcoidosis in rheumatoid arthritis: FDG PET findings. Clin Nucl Med. (2015) 40:58-61. doi: 10.1097/RLU.0000000000000582

166. Herbert VG, Blodorn-Schlicht N, Boer-Auer A. Cutaneous granulomatous reactions at botulinum neurotoxin a injection sites: first manifestation of systemic sarcoidosis. Hautarzt. (2015) 66:863-6. doi: 10.1007/s00105-015-3651-8

167. Callejas-Rubio JL, Lopez-Perez L, Ortego-Centeno N. Tumor necrosis factor-alpha inhibitor treatment for sarcoidosis. Ther Clin Risk Manage. (2008) 4:1305-13. doi: 10.2147/TCRM.S967

168. Zisman DA, McCune WJ, Tino G, Lynch JP III. Drug-induced pneumonitis: the role of methotrexate. Sarcoidosis Vasc Diffuse Lung Dis. (2001) 18:243-52.

169. Fantini F, Padalino C, Gualdi G, Monari P, Giannetti A. Cutaneous lesions as initial signs of interferon alpha-induced sarcoidosis: report of three new cases and review of the literature. Dermatol Ther. (2009) 22(Suppl. 1):S1-7. doi: 10.1111/j.1529-8019.2009.01263.x

170. Gitlin N. Manifestation of sarcoidosis during interferon and ribavirin therapy for chronic hepatitis C: a report of two cases. Eur J Gastroenterol Hepatol. (2002) 14:883-5. doi: 10.1097/00042737-20020800000013

171. Shiki M, Hida T, Yamashita T. Development of sarcoidosis during $\beta$-interferon therapy for melanoma. J Dermatol. (2014) 41:862-3. doi: $10.1111 / 1346-8138.12581$
172. Bobbio-Pallavicini E, Valsecchi C, Tacconi F, Moroni M, Porta C. Sarcoidosis following beta-interferon therapy for multiple myeloma. Sarcoidosis. (1995) 12:140-2.

173. Dhaille F, Viseux V, Caudron A, et al. Cutaneous sarcoidosis occurring during anti-TNF-alpha treatment: report of two cases. Dermatology. (2010) 220:234-7. doi: 10.1159/000275676

174. Skoie IM, Wildhagen K, Omdal R. Development of sarcoidosis following etanercept treatment: a report of three cases. Rheumatol Int. (2012) 32:104953. doi: 10.1007/s00296-009-1349-x

175. Garrido MC, Gutierrez C, Riveiro-Falkenbach E, Ortiz P, RodriguezPeralto JL. BRAF inhibitor-induced antitumoral granulomatous dermatitis Eruption in advanced melanoma. Am J Dermatopathol. (2015) 37:795-8. doi: 10.1097/DAD.0000000000000281

176. Park JJ, Hawryluk EB, Tahan SR, Flaherty K, Kim CC. Cutaneous granulomatous eruption and successful response to potent topical steroids in patients undergoing targeted BRAF inhibitor treatment for metastatic melanoma. JAMA Dermatol. (2014) 150:307-11. doi: 10.1001/jamadermatol.2013.7919

177. Friedman BE, English JC III. Drug-induced sarcoidosis in a patient treated with an interleukin-1 receptor antagonist for hidradenitis suppurativa. JAAD Case Rep. (2018) 4:543-5. doi: 10.1016/j.jdcr.2018.03.007

178. Firwana B, Ravilla R, Raval M, Hutchins L, Mahmoud F. Sarcoidosis-like syndrome and lymphadenopathy due to checkpoint inhibitors. J Oncol Pharm Pract. (2017) 23:620-4. doi: 10.1177/1078155216667635

179. Wilgenhof S, Morlion V, Seghers AC, Du Four S, Vanderlinden E, Hanon S, et al. Sarcoidosis in a patient with metastatic melanoma sequentially treated with anti-CTLA-4 monoclonal antibody and selective BRAF inhibitor. Anticancer Res. (2012) 32:1355-9.

180. Gomez V, Smith PR, Burack J, Daley R, Rosa U. Sarcoidosis after antiretroviral therapy in a patient with acquired immunodeficiency syndrome. Clin Infect Dis. (2000) 31:1278-80. doi: 10.1086/ 317422

181. Balbouzis T, Georgiadis T, Grigoris P. Granulomatous lung disease: a novel complication following metallosis from hip arthroplasty. Hip Pelvis. (2016) 28:249-53. doi: 10.5371/hp.2016.28.4.249

182. Jacobs JJ, Urban RM, Wall J, Black J, Reid JD, Veneman L. Unusual foreignbody reaction to a failed total knee replacement: simulation of a sarcoma clinically and a sarcoid histologically. A case report. J Bone Joint Surg Am. (1995) 77:444-51. doi: 10.2106/00004623-199503000-00015

183. Shoenfeld Y, Agmon-Levin N. 'ASIA' - autoimmune/inflammatory syndrome induced by adjuvants. J Autoimmun. (2011) 36:4-8. doi: 10.1016/j.jaut.2010.07.003

184. Yoshida T, Tanaka M, Okamoto K, Hirai S. Neurosarcoidosis following augmentation mammoplasty with silicone. Neurol Res. (1996) 18:319-20. doi: 10.1080/01616412.1996.11740428

185. Roberts WC, McAllister HA Jr, Ferrans VJ. Sarcoidosis of the heart. A clinicopathologic study of 35 necropsy patients (group 1) and review of 78 previously described necropsy patients (group 11). Am J Med. (1977) 63:86-108. doi: 10.1016/0002-9343(77)90121-8

186. Sekiguchi M, Numao Y, Imai M, Furuie T, Mikami R. Clinical and histopathological profile of sarcoidosis of the heart and acute idiopathic myocarditis. Concepts through a study employing endomyocardial biopsy. I. Sarcoidosis. Jpn Circ J. (1980) 44:249-63. doi: 10.1253/jcj.44.249

187. Bagwan IN, Hooper LV, Sheppard MN. Cardiac sarcoidosis and sudden death. The heart may look normal or mimic other cardiomyopathies. Virchows Arch. (2011) 458:671-8. doi: 10.1007/s00428-010-1003-8

188. Yazaki Y, Isobe M, Hiramitsu S, Morimoto S, Hiroe M, Omichi C, et al. Comparison of clinical features and prognosis of cardiac sarcoidosis and idiopathic dilated cardiomyopathy. Am J Cardiol. (1998) 82:537-40. doi: 10.1016/S0002-9149(98)00377-4

189. Yoshizawa S, Kato TS, Mancini D, Marboe CC. Outcome of patients having heart transplantation for lymphocytic myocarditis. Am J Cardiol. (2013) 112:405-10. doi: 10.1016/j.amjcard.2013.03.042

190. Kang EJ, Kim SM, Choe YH, Lee GY, Lee KN, Kim DK. Takayasu arteritis: assessment of coronary arterial abnormalities with 128-section dual-source CT angiography of the coronary arteries and aorta. Radiology. (2014) 270:7481. doi: 10.1148/radiol.13122195 
191. Mohty D, Damy T, Cosnay P, Echahidi N, Casset-Senon D, Virot P, et al. Cardiac amyloidosis: updates in diagnosis and management. Arch Cardiovasc Dis. (2013) 106:528-40. doi: 10.1016/j.acvd.2013.06.051

192. Nunes MC, Dones W, Morillo CA, Encina JJ, Ribeiro AL, Council on Chagas Disease of the Interamerican Society of Cardiology. Council on chagas disease of the interamerican society of cardiology. Chagas disease: an overview of clinical and epidemiological aspects. J Am Coll Cardiol. (2013) 62:767-76. doi: 10.1016/j.jacc.2013.05.046

193. Lynch JP 3rd, Hwang J, Bradfield J, Fishbein M, Shivkumar K, Tung R. Cardiac involvement in sarcoidosis: evolving concepts in diagnosis and treatment. Semin Respir Crit Care Med. (2014) 35:372-90. doi: 10.1055/s-0034-1376889

194. Houston BA, Mukherjee M. Cardiac sarcoidosis: clinical manifestations, imaging characteristics, and therapeutic approach. Clin Med Insights Cardiol. (2014) 8:31-7. doi: 10.4137/CMC.S15713

195. Chen J, Lei J, Scalzetti E, McGrath M, Feiglin D, Voelker R, et al. Myocardial contractile patterns predict future cardiac events in sarcoidosis. Int $J$ Cardiovasc Imaging. (2018) 34:251-62. doi: 10.1007/s10554-017-1233-9

196. Fields CL, Ossorio MA, Roy TM, Denny DM, Varga DW. Thallium-201 scintigraphy in the diagnosis and management of myocardial sarcoidosis. South Med J. (1990) 83:339-42. doi: 10.1097/00007611-199003000-00022

197. White JA, Rajchl M, Butler J, Thompson RT, Prato FS, Wisenberg G. Active cardiac sarcoidosis: first clinical experience of simultaneous positron emission tomography-magnetic resonance imaging for the diagnosis of cardiac disease. Circulation. (2013) 127:e639-41. doi: 10.1161/CIRCULATIONAHA.112.001217

198. Ohira H, Tsujino I, Ishimaru S, Oyama N, Takei T, Tsukamoto E, et al. Myocardial imaging with 18F-fluoro-2-deoxyglucose positron emission tomography and magnetic resonance imaging in sarcoidosis. Eur J Nucl Med Mol Imaging. (2008) 35:933-41. doi: 10.1007/s00259-007-0650-8

199. Moraes GL, Higgins CB, Ordovas KG. Delayed enhancement magnetic resonance imaging in nonischemic myocardial disease. J Thorac Imaging. (2013) 28:84-92. doi: 10.1097/RTI.0b013e3182828f89

200. Maron BJ. Hypertrophic cardiomyopathy: a systematic review. JAMA. (2002) 287:1308-20. doi: 10.1001/jama.287.10.1308

201. Maceira AM, Joshi J, Prasad SK, Moon JC, Perugini E, Harding I, et al. Cardiovascular magnetic resonance in cardiac amyloidosis. Circulation. (2005) 111:186-93. doi: 10.1161/01.CIR.0000152819.97857.9D

202. Zipse MM, Sauer WH. Cardiac sarcoidosis. Curr Cardiol Rep. (2014) 16:514. doi: 10.1007/s11886-014-0514-3

203. Chapelon-Abric C. Cardiac sarcoidosis. Curr Opin Pulm Med. (2013) 19:493-502. doi: 10.1097/MCP.0b013e32836436da

204. Valantine HA, Tazelaar HD, Macoviak J, Mullin AV, Hunt SA, Fowler MB, et al. Cardiac sarcoidosis: response to steroids and transplantation. J Heart Transplant. (1987) 6:244-50.

205. Ishikawa T, Kondoh H, Nakagawa S, Koiwaya Y, Tanaka K. Steroid therapy in cardiac sarcoidosis. Chest. (1984) 85:445-7. doi: 10.1378/chest.85.3.445

206. Oni AA, Hershberger RE, Norman DJ, Ray J, Hovaguimian H, Cobanoglu $\mathrm{AM}$, et al. Recurrence of sarcoidosis in a cardiac allograft: control with augmented corticosteroids. J Heart Lung Transplant. (1992) 11(2 Pt 1):367-9.

207. Al-Kofahi K, Korsten P, Ascoli C, Virupannavar S, Mirsaeidi M, Chang I, et al. Management of extrapulmonary sarcoidosis: challenges and solutions. Ther Clin Risk Manag. (2016) 12:1623-34. doi: 10.2147/TCRM.S74476
208. Boursiquot JN, Gérard L, Malphettes M, Fieschi C, Galicier L, Boutboul $\mathrm{D}$, et al. Granulomatous disease in CVID: a retrospective analysis of clinical characteristics and treatment efficacy in a cohort of 59 patients. J Clin Immunol. (2013) 33:84-95. doi: 10.1007/s10875-0129778-9

209. Allaoui A, Moudatir M, Echchilal K, Alaoui FZ, Elkabli H. A misleading diagnosis of sarcoidosis in an older woman. Eur J Case Rep Intern Med. (2017) 4:000463. doi: 10.12890/2017_000463

210. Ho H-E, Cunningham-Rundles C. Non-infectious complications of common variable immunodeficiency: updated clinical spectrum, sequelae, and insights to pathogenesis. Front Immnol. (2020) 11:149. doi: 10.3389/fimmu.2020.00149

211. Cowen JE, Stevenson J, Paravasthu M, Darroch J, Jacob A, Tueger S, et al. Common variable immunodeficiency with granulomatous-lymphocytic interstitial lung disease and preceding neurological involvement: a case-report. BMC Pulm Med. (2020) 20:205. doi: 10.1186/s12890-020-0 1231-6

212. Mannina A, Chung JH, Swigris JJ, Solomon JJ, Huie TJ, Yunt ZX, et al. Clinical predictors of a diagnosis of common variable immunodeficiencyrelated granulomatous-lymphocytic interstitial lung disease. Ann Am Thorac Soc. (2016) 13:1042-9. doi: 10.1513/AnnalsATS.201511-728OC

213. Bates CA, Ellison MC, Lynch D, Cool CD, Brown KK, Routes JM. Granulomatous-lymphocytic lung disease shortens survival in common variable immunodeficiency. J Allergy Immunol. (2004) 114:415-21. doi: 10.1016/j.jaci.2004.05.057

214. Oksenhendler E, Gerard L, Fieschi C, Malphettes M, Mouillot G, Jaussaud $\mathrm{R}$, et al. DEFI study group. Infections in 252 patients with common variable immunodeficiency. Clin Infect Dis. (2008) 46:1547-54. doi: 10.1086/587669

215. Chapel H, Lucas M, Lee M, Bjorkander J, Webster D, Grimbacher B, et al. Common variable immunodeficiency disorders: division into distinct clinical phenotypes. Blood. (2008) 112:277-86. doi: 10.1182/blood-2007-11124545

216. Bouvry D, Mouthon L, Brillet PY, Kambouchner M, Ducroix JP, Groupe sarcoidose francophone, et al. Granulomatous-associated common variable immunodeficiency disorder: a case-control study versus sarcoidosis. Eur Respir J. (2013) 41:115-22. doi: 10.1183/09031936.00189011

217. Abbott JK, Gelfand EW. Common variable immunodeficiency: diagnosis, management, and treatment. Immunol Allergy Clin North Am. (2015) 35:637-58. doi: 10.1016/j.iac.2015.07.009

218. Shanks AM, Alluri R, Herriot R, Dempsey O. Misdiagnosis of common variable immune deficiency. BMJ Case Rep. (2014) 2014:bcr2013202806. doi: 10.1136/bcr-2013-202806

Conflict of Interest: The authors declare that the research was conducted in the absence of any commercial or financial relationships that could be construed as a potential conflict of interest.

Copyright (c) 2021 Narula and Iannuzzi. This is an open-access article distributed under the terms of the Creative Commons Attribution License (CC BY). The use, distribution or reproduction in other forums is permitted, provided the original author(s) and the copyright owner(s) are credited and that the original publication in this journal is cited, in accordance with accepted academic practice. No use, distribution or reproduction is permitted which does not comply with these terms. 